\title{
A Deseda-tó környékének éjjeli nagylepke faunája (Lepidoptera: Heterocera)
}

\author{
SCHMIDT PÉTER \\ Rippl-Rónai Múzeum, H-7400 Kaposvár, Fő utca 10., \\ e-mail: peter.schmidt.smmi@gmail.com
}

\begin{abstract}
ScHMIDT, P.: The moth fauna of the Lake Deseda and its surroundings (Lepidoptera: Heterocera).

Abstract: In this paper, the author publishes the results of his 2 years long research of the Heterocera-fauna around the Lake Deseda, Somogy county, Hungary. Altogether 386 Heterocera species were found by both lamping and light trapping from 9 selected sampling locations. Also, the biogeographical and ecological analyses are given of these species. 7 protected and 1 strictly protected taxa were found. 3 of them are considered endangered species (Chariaspilates formosaria, Polypogon gryphalis, Dioszeghyana schmidtii).
\end{abstract}

Keywords: Moths, Heterocera, Somogy, Deseda, faunistic research, nature conservation

\section{Bevezetés}

A Deseda-tó és Környéke Helyi Jelentőségü Természetvédelmi Területet 1994-ben nyilvánították védetté. Területe 1112 ha. Kijelölésének elsődleges célja a víztározó körül kialakult természetközeli élőhelyek védelme, valamint az ezekben a biotópokban élő állatfajok állományainak megőrzése volt. A tó környékének az északi részén jelentős és viszonylag jó állapotú erdőterületek maradtak fenn, jellemzően illír gyertyános-tölgyesek (Helleboro dumetorum-Carpinetum). Helyenként ezek termőhelyén cser telepítés következtében a cser elegyaránya jelentős mértékben megnőtt, homogén cseresek (keményfás jellegtelen erdők) is előfordulnak. A terület déli felében a vízhez erősen kötődő társulások jelentik a fő természeti értéket. Az ezekben a viszonylag természetközeli növénytársulásokban élő rovarfaunáról azonban nem voltak pontos adatok, az éjszakai lepkefaunájuk majdhogynem teljesen ismeretlen volt.

Magyarországon jelenleg 1274 nagylepke faj honos, amelyből 162 nappali (Diurna), 1112 éjjeli (Heterocera) faj (VARGA 2010). ÁBRAHÁM és UHERKOVICH (2001) által a megye faunakatalógusában összegzett, Somogy megyében előforduló fajok száma: Macrolepidoptera: 981, Diurna: 128, Heterocera: 853. Ezeknek az adatoknak a teljes magyarországi nagylepke faunához viszonyított aránya $77 \%$ (Diurna: 79\%, Heterocera: 76,7\%).

A jelen kutatáshoz hasonló alaposságú nagylepke felmérés a vizsgált terület környékén csak két helyszínen, a Zselici Tájvédelmi Körzetben, valamint a Boronkamelléki Tájvédelmi Körzetben történt. A Deseda-tó környéki területhez közelebb áll földrajzilag és a megtalálható élöhelytípusok szempontjából is a Zselic. Különösen a Kaposvárhoz közelebbi része, a Zselici Tájvédelmi Körzet számít jól feltártnak (KovÁcs 1953, 1956), amely területről az 1970-es évektől kezdve az 1990-es évek elejéig több alkalommal születtek alapos nagylepke-faunisztikai munkák (ÁBRAHÁM 1992b, UHERKOVICH 1978a, 1981a), valamint azt követően is kiegészítő jellegű publikációk (SzABó 2007). Ezeknek a felméréseknek az összegzése alapján elmondható, hogy összesen 753 éjjeli nagylepke fajt mutattak ki eddig a Zselicből. Ez a teljes hazai faunának a $68 \%$-a, a megyei faunának pedig a $88 \%$-a.

A mintaterülettől nyugati irányban fekvő összefüggő, és többé-kevésbé természetközeli állapotú terület a Boronka-melléki Tájvédelmi Körzet. A területen ÁBRAHÁM (1992a) végzett átfogó Macrolepidoptera felmérést. Ekkor 580 éjjeli nagylepke-fajt sikerült kimutatni, az országos fauna $52 \%$-át, Somogy megye teljes faunájának a 68\%-át.

Már elöljáróban is fontos azonban látni, hogy e két tájvédelmi körzet területe sokszorosa a vizsgáltnak (különösen, ha azt is figyelembe vesszük, hogy a vizsgált védett terület nagy része maga a Deseda-tó nyílt vízfelszíne), így itt az élőhelyek diverzitása és mérete is jelentősen szerényebb, amiből következik, hogy a Deseda-környéki rovarfauna fajszáma várhatóan elmarad az összehasonlított területek hasonló adatától.

\section{Anyag és módszer}

A vizsgálat helyszínéül választott, közepesen jó természeti állapotú terület déli és nyugati részén közigazgatásilag Kaposvárhoz, északnyugati részén Magyaregreshez, északkeleti részén pedig Somogyaszalóhoz tartozik. A legközelebbi, országos védelem alatt álló terület a Deseda-tótól északra, a Mernyei-erdő Natura 2000 terület (HUDD20019).

A vizsgált terület földrajzi elhelyezkedését tekintve a Dunántúli-dombságon, azon belül a Dél-KülsőSomogy kistáj délnyugati határán terül el (Dövényi 2010). A kistáj éghajlata alapvetően mérsékelten meleg, mérsékelten nedves. Évi középhőmérséklete 10 $10,3^{\circ} \mathrm{C}$, de a vegetációs időszak középhőmérséklete eléri akár a $17{ }^{\circ} \mathrm{C}$-ot is. Az éves napfénytartam 2000 2020 óra. Fontos és meghatározó éghajlati tényező a csapadék mennyisége is: a Dél-Külső-Somogy kistáj átlagos évi csapadékösszege 680-700 mm, amiből hozzávetőlegesen $400 \mathrm{~mm}$ a vegetációs periódus alatt hullik (DövÉNYı 2010). Az utóbbi évtizedben a csapadék vegetációs időszakon belüli eloszlása egyértelműen átalakult: tavasszal és ősszel is egyre jellemzőbbek az akár 2-3 hetes csapadék nélküli periódusok, az egyre gyakoribb nyári aszályok között pedig a nyári „csendes” esők szinte teljesen megszüntek, helyettük 
az özönvízszerű zivatarok a gyakoriak, amelyek során akár néhány óra alatt 2-3 hétnyi csapadék hullik le.

A területen a rovarfauna szempontjából a következő jellegzetes élőhelytípusok találhatóak: cserrel elegyes erdők (keményfás jellegtelen erdők, cserrel elegyes gyertyános-kocsánytalan tölgyesek), üde gyertyános-kocsánytalan tölgyesek (Helleboro dumetorumCarpinetum), jóval kisebb kiterjedésben füz és nyár uralta puhafás erdők (őshonos fafajú puhafás jellegtelen erdők), patakkísérő égerligetek (Carici pendulae-Alnetum). Ezek mára igen kis kiterjedésben maradtak csak fenn, és csupán egy részük természetközeli állapotú.

A 2017 nyarától 2019 nyaráig tartó vizsgálatsorozat mintavételi helyeinek meghatározásakor a Heterocerafauna minél szélesebb feltárása volt a cél, ezért 9 mintavételi helyet jelöltem ki (1. ábra).

A vizsgálat során 2 mintavételi módszert alkalmaztam: fénycsapdázást és lámpázást. A kijelölt helyszíneken összesen 49 alkalommal történt mintavétel (2017: 13, 2018: 28, 2019: 8), ezek közül nagyjából egyenlő arányban történt fénycsapdázás, lámpázás, valamint egyes éjszakák alatt párhuzamosan mindket- tő. Mennyiségi adatok csak az értékes és/vagy védett fajok esetében kerültek feljegyzésre.

A fénycsapdázás során hordozható fénycsapdákat alkalmaztam, egyszerre általában kettőt vagy hármat, amelyeket egymástól megfelelő távolságban vagy egymáshoz képest takarva állítottam fel. Ezek fényforrása 8 W-os UV fénycső volt, amelyet 7 Ah-ás akkumulátorok működtettek. A fénycsapdázás csak 2017-ben és 2018-ban folyt, amely során a mintavételi helyek általános és gyakori fajai jól kirajzolódtak. Ezzel párhuzamosan, valamint 2019 első felében lámpázásokat is végeztem a mintavételi helyszíneken a terület ritka, nagyon alacsony egyedszámú fajainak a feltérképezéséhez. A lámpázás során 160 W-os higanygőzlámpát használtam, amelyet Honda Eu 22i típusú áramfejlesztővel müködtettem.

A mintaterületen észlelt fajokból kialakított teljes faunalista mellett a megtalált taxonok állatföldrajzi és ökológiai beosztása is megvitatásra kerül, amely alapján következtetni lehet, hogy melyek a sérülékenyebb és veszélyeztetettebb fajok (UHERKOVICH 1975, VARGA 1964, 2003).

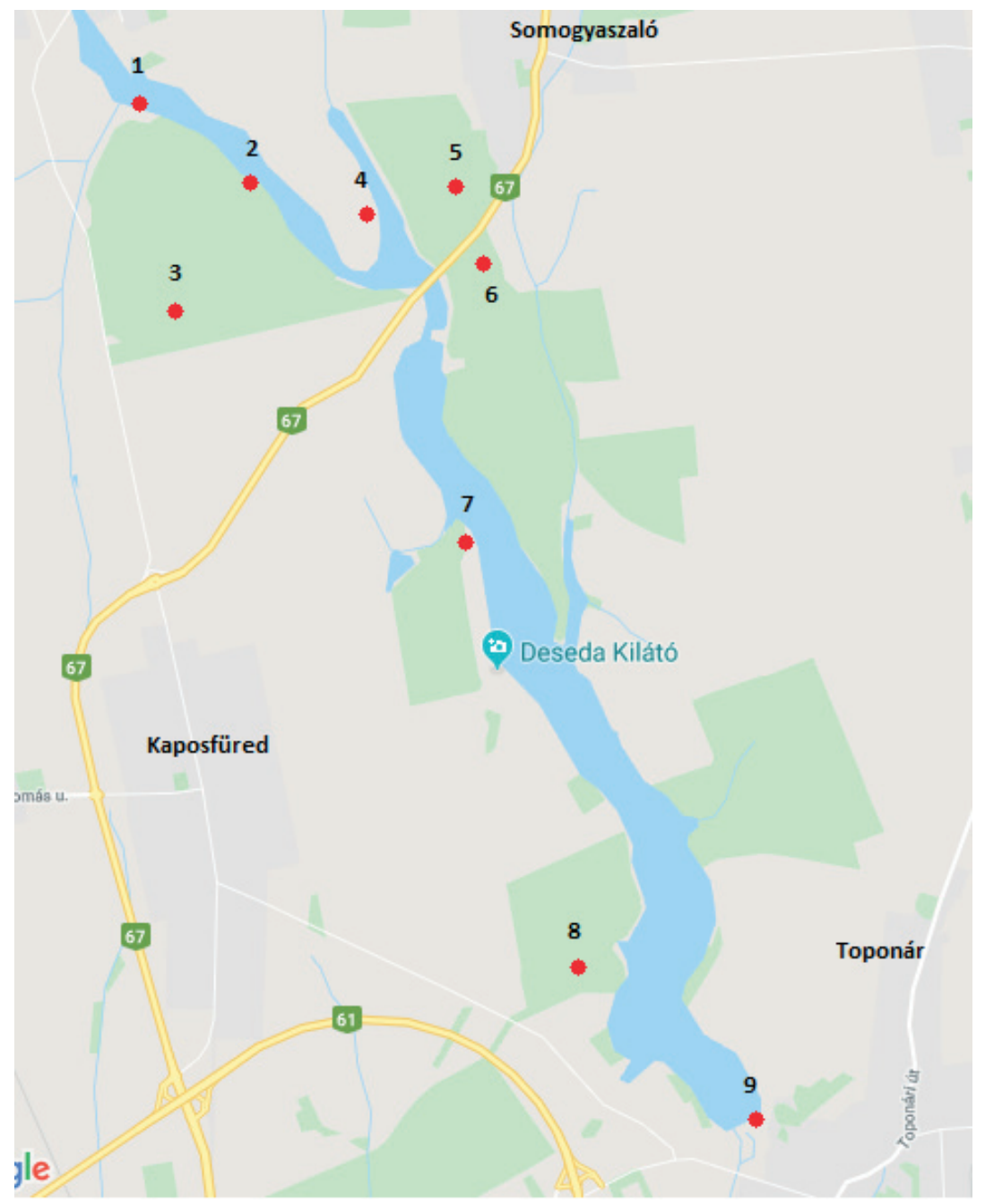

1. ábra. A Deseda-tó és környékének térképe a mintavételi helyekkel (forrás: Google Maps, szerk. a szerző) 


\section{Eredmények}

A Deseda-víztározó környékén végzett két éven át tartó faunisztikai vizsgálat során összesen 386 éjjeli nagylepke-faj került elő a mintaterületről - ebből 5 faj a Microlepidopterák közé tartozik, amelyek föként a könnyü határozhatóság miatt kerültek feljegyzésre (1. táblázat). A vizsgálat során - kevés kivételtől eltekintve, elsősorban a védett és ritka fajokkal kapcsolatban - mennyiségi adatok nem kerültek feljegyzésre csak a jelenlét/hiány állapítható meg, így a fajok gyakoriságára nem lehet biztosan következtetni. Meg lehet vizsgálni, hogy melyek azok a fajok, amelyek több (esetleg az összes) mintavételi helyröl előkerültek, de ez nem ad pontos képet a faj gyakoriságáról/ritkaságáról. Több esetben előfordult, hogy egy faj sok helyröl előkerült, de mindig alacsony egyedszámban, ugyanakkor jó pár másik csupán 1-2 lelőhelyen mutatkozott, de ott kiemelkedő példányszámban.

A mintavételi helyek pontos meghatározása:

1: Magyaregres, Varga-Bonyi-árok, (MVB) - É. sz. $46,4507^{\circ}$ K. h. $17,7721^{\circ}$

2: Magyaregres, Gombási-erdő, tópart, (MGT) - É. sz. $46,4442^{\circ}$ K. h. $17,7843^{\circ}$

3: Magyaregres, Gombási-erdő, (MG)-É. sz. 46,4383 K. h. $17,7749^{\circ}$

4: Arborétum, (A) - É. sz. $46,4444^{\circ}$ K. h. $17,7914^{\circ}$

5: Somogyaszaló, Deseda-erdő, (SD) - É. sz. 46,4446 ${ }^{\circ}$ K. h. $17,7972^{\circ}$

6: Somogyaszaló, Halomsírok, (SH) - É. sz. 46,4421 K. h. $17,7996^{\circ}$

7: Kaposfüred-szőlőhegy, (KSZ) - É. sz. 46,4258 K. h. $17,7991^{\circ}$

8: Kaposfüred, Községi-erdő, (KK) - É. sz. 46,4044 K. h. $17,8072^{\circ}$

9: Toponár, Desedai-rét, (TD) - É. h. $46,3944^{\circ} \mathrm{K}$. h. $17,8199^{\circ}$

A megtalált fajok állatföldrajzi besorolás szerinti megoszlásának összegzett ábrájából (2. ábra) jól látható, hogy a fajok pontosan 2/3-a (66\%) euroszibériai elterjedésü, tehát a mérsékelt övi Eurázsia nagy részén előforduló, széles körben elterjedt taxon. A fauna értékesebb tagjait a mediterrán elterjedésű, déli, melegkedvelő fajok alkotják (27\%). A mintaterület dél-dunántúli elhelyezkedése miatt magasabb ez az arány az országos értékhez képest. A diszjunkt elterjedésü sybilla faunaelemek aránya alacsony, ilyen megtalált fajok például a Pelosia obtusa vagy a Chariaspilates formosaria. Ezeken kívül néhány holarktikus taxon is előkerült, valamint az „egyéb” kategóriába a nearktikus, a mandzsúriai, a pacifikus fajok kerültek.

A kutatás során jegyzett fajok ökológiai beosztás szerinti összegzett ábrájából arra következtethetünk (3. ábra), hogy a Deseda-tó környékén a zonális lombhullató erdő a természetes növénytakaró, hiszen az éjszakai nagylepke fauna 41\%-a zonális erdőlakó faj (sylvicol, quercetális, nemorális, pinetális, pubescentális). A fauna 21\%-a gyepekhez kötődő fajnak minősül (szárazgyepi-sztyep, mezofil, lápréti, arundifil, altoherbosa). Euryök, vagyis tágtürésü, gya- korlatilag minden természetközeli és bolygatott élöhelyen is előforduló fajok teszik ki a desedai fauna $20 \%$ át. Viszonylag jelentős azon fajok aránya (14\%), amelyek az azonális, vagyis elsősorban nem a hőmérséklet és a domborzat, hanem jelen esetben a rendelkezésre álló vízmennyiség által fenntartott erdőkhöz kötöttek (láperdei, füz-nyár, nyír-éger fajok). Ezek legtöbbször táplálékspecialisták, ezáltal veszélyeztetettebb és értékesebb faunakomponensek.

A terepi tapasztalatok és a begyűjtött adatok elemzését követően rövid természetvédelmi értékelést adhatunk a Deseda-víztározó környékének nagylepke faunájáról. Összesen: 386 éjjeli nagylepke-fajt sikerült megtalálni, ezek közül 8 jogszabályi oltalmat élvez (Magyar Közlöny 2015). Ezek a következők: Saturnia pyri, Euplagia quadripunctaria, Drymonia velitaris, Chariaspilates formosaria, Idia calvaria, Polypogon gryphalis, Dioszeghyana schmidtii, Naenia typica. 7 védett faj mellett 1 fokozottan védett fordul elő a vizsgált területen, ezek közül pedig 2 Natura 2000 jelölőfaj is. Bár a jelen vizsgálatsorozat elsősorban az éjjeli nagylepkékre fókuszált, a víztározó környékét számtalan alkalommal bejártam nappal is. Ezen bejárások során több értékes nappali lepkefaj is előkerült, amelyek közül a következő fajokat érdemes kiemelni. A Parnassius mnemosyne és az Euphydryas maturna az északi rész gyertyános-tölgyeseiben fordul elő. Cserrel elegyes gyertyános-tölgyesek lékeiben és szegélyeiben fordul elö a Neozephyrus quercus és a Satyrium ilicis. A Lycaena dispar túzlepkét az északi részen, a Desedapatak felduzzasztott része előtt találtam meg Thecla betulae-populáció társaságában. A vizsgált terület legértékesebb nappali lepkefajának, a Pyronia tithonus fajnak az egyedeit szintén ezen a részen, a patakvölgy keleti oldalán, kökényes legelő tetején jegyeztem fel.

A vizsgálat során előkerült éjszakai lepkék közül 3 fajt érdemes kiemelni, amelyek országos szinten is értékes és ritka fajoknak számítanak.

\section{Lápi tarkaaraszoló - Chariaspilates formosaria (Eversmann, 1837)}

Szép külleme miatt más lepkefajjal nem téveszthető össze ez a természetvédelmi szempontból kiemelkedően értékes araszolófaj. Diszjunkt elterjedésű, lápi faj, amely Közép- és Kelet-Európában nagyon lokálisan, míg Kelet-Ázsiában széles körben elterjedt. A magyarországi populációk külön alfajt képviselnek (subsp. pannonica), ezért állatföldrajzi szempontból kiemelkedően nagy értékűek. A Dél-Dunántúlon a Dráva-mentén (UHERKOVICH 1978b), a Baláta-tónál, valamint a Nagy-berek és a Látrányi Puszta Természetvédelmi Területen (ÁBRAHÁM 2003) fordul elő. A faj erősen kötődik a jó vízellátású magassásos láprétekhez. Az ilyen élőhelyek eltűnése (kiszáradás, szukcesszió, becserjésedés, inváziós fajok (Solidago sp.) kiemelten veszélyeztetik megmaradt populációit. A vizsgált terület egyik legértékesebb lepkefaja, ugyanakkor nedvességigénye miatt az egyik legveszélyeztetettebb is. A víztározó gátja alatti területen 2018-ban 1, 2019-ben 6 példánya jött a fényforráshoz (4. ábra). 


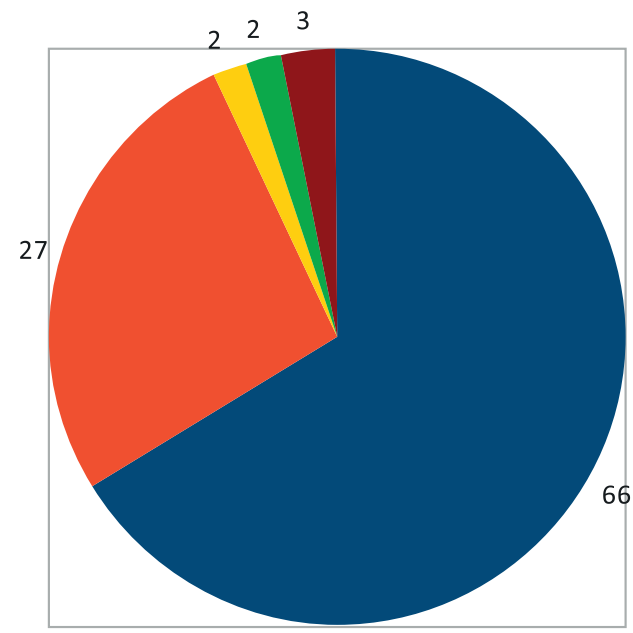

Euroszibériai

Mediterrán

Sybilla

- Holarktikus

Egyéb

2. ábra. A fajok állatföldrajzi beosztás szerinti megoszlása (\%).

31

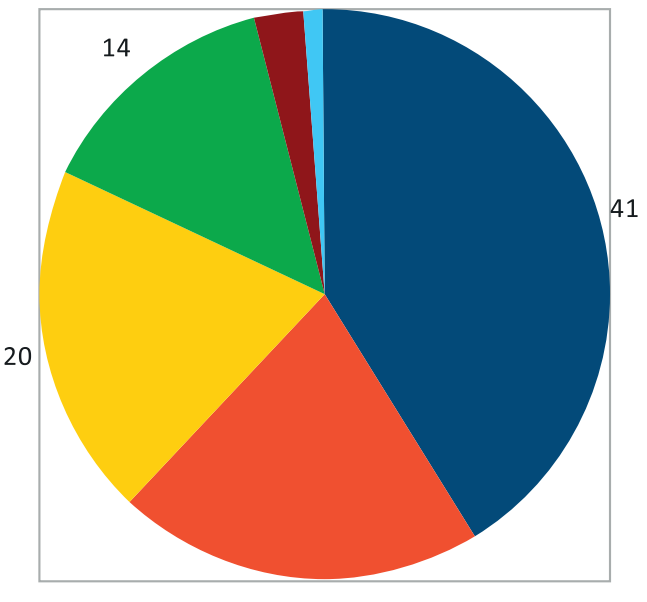

Zonális erdőlakó

Gyepi fajok

Euryök

Azonális erdőlakó

- Adventív/Expanzív/Vándor faj

Egyéb

21

3. ábra. A fajok összegzett biogeográfiai beosztás szerinti megoszlása (\%).

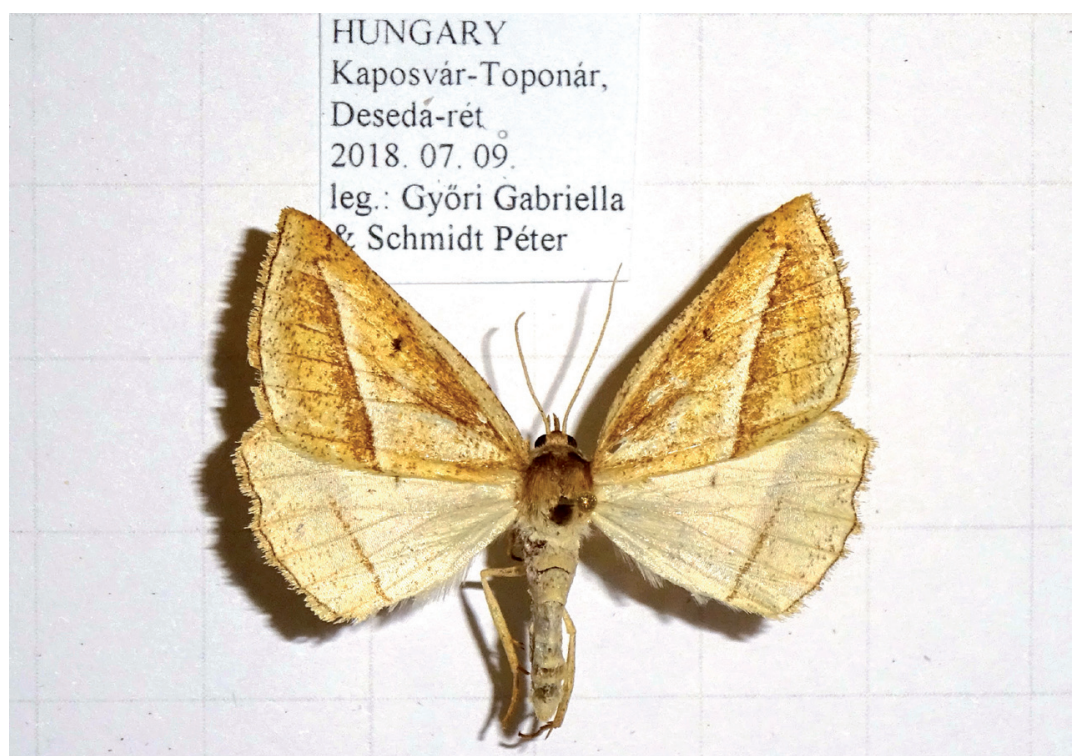

4. ábra. Lápi tarkaaraszoló - Chariaspilates formosaria (Eversmann, 1837). 


\section{Láperdei karcsúbagoly - Polypogon gryphalis (Herrich-Schaffer, 1851)}

Nagyon szűk elterjedési területű, európai lepkefaj. Diszjunkt, foltszerű areája az Alpok déli részénél nyúlik el DK-Franciaországtól Nyugat-Ukrajnáig. Hazánkban kevés helyröl, föként a Dunántúlról ismert, mindenhol ritka faj, bár gyakoriságára a hullámzó tendencia jellemző. Lápréteken és láperdőkben fordul elő. A Deseda környékén néhány egyede került elő.

\section{Magyar tavaszi-fésűsbagoly - Dioszeghyana schmidtii (Diószeghy, 1935)}

Fokozottan védett, egyben Natura 2000 jelölő éjjeli lepkénk. Nagyon szük elterjedési területe a Kárpát-medencére, az Észak-Balkán bizonyos pontjaira, valamint Törökország egy kis részére terjed ki. Fő tápnövényei a molyhos és a csertölgy (Quercus pubescens, Q. cerris). Korábban sokkal ritkább volt: főként alföldi lösztölgyesekből, valamint az Északi-középhegység déli oldaláról volt ismert. Mára jóval gyakoribbá vált (megjelent a Dunántúli-középhegységben, valamint a Dél-Dunántúlon is), ami valószínüleg a melegedő klímának tudható be. A vizsgált terület egyik legértékesebb éjjeli nagylepkéje. Eddig elenyésző számú publikált adata volt a DélDunántúlról, pedig valószínűleg jóval elterjedtebb itt is. A Deseda környékén a Somogyaszalóhoz tartozó erdőrészekből került elő. 2018-ban csak 3 egyed, 2019-ben viszont 15-20 példánya jött a fényre.

Mindenképpen érdemes néhány nem védett, de igen értékes és veszélyeztetett éjjeli fajt is kiemelni. Ezen fajok mindegyike, bár nem védettek, de azokhoz hasonlóan kistáji szinten jelentős természetvédelmi értéket képviselő taxonok. Ilyenek például: Drepana curvatula, Cerura erminea, Harpyia milhauseri, Arcia caja, Pelosia obtusa, Cepphis advenaria, Hypenodes humidalis, Eutelia adulatrix, Calophasia lunula, Atethmia centrago, Noctua interjecta. Ezek közül a cserszömörcebagoly (Eutelia adulatrix) a legkülönlegesebb lepkefaj, amely a vizsgálat során elökerült a területröl. Ez a karsztbokorerdőkhöz kötődő faj a cserszömörcén (Cotinus coggygria) fejlődik. Tápnövényének állományai közelében nem ritka, sőt a Dunántúli-középhegység déli kitettségü, meleg biotópjaiban igen gyakori is lehet. A vizsgált területen azonban kifejezetten meglepő a felbukkanása, különösen úgy, hogy az egyetlen megkerült egyed a déli részen, patak menti nedves ligetben jött a fényre. A vizsgált területhez legközelebb a Mecsekben tenyészik. Valószínüleg a Kaposvárt északról elkerülő gyorsforgalmi út mentén ültetett cserszömörce bokrokon tudott kifejlődni a begyűjtött egyed. Faunisztikai szempontból is kiemelkedő érdekesség, ugyanis ez a második publikált példánya a fajnak Somogy megyéböl (ScHMIDT 2019). Az elsőt több mint 50 évvel ezelőtt Balatonszabadinál gyűjtötték (RÉZBÁNYAI 1972).

\section{Diszkusszió}

A Deseda-víztározó környékén végzett, 2 éven át tartó felméréssorozat során összesen 386 éjjeli nagylepkefaj előfordulását sikerült kimutatni. A Zselici Tájvédelmi Körzetben megtalált fajoknak ez az 51\%-a, míg a Boronka-melléki Tájvédelmi Körzetből ismerteknek a 65,5\%-a. Jelen kutatás során sikerült megtalálni 2 olyan fajt, amelyek egyik tájvédelmi körzetből sem kerültek eddig elő: lápi tarkaaraszoló (Chariaspilates formosaria) és cserszömörcebagoly (Eutelia adulatrix). A Somogy megyéből ismert éjjeli nagylepkéknek a 45\%-a került elő a Deseda-víztározó környékéröl. Nem sikerült olyan fajt kimutatni, amely még nem került elő Somogy megyéből. Azonban a tájvédelmi körzetek faunisztikai elemzései más skálán történtek és nem a jelen vizsgálathoz területnagyságban közelítő mértékben. A Deseda-tó környéki megfelelő élöhelyek területe csak töredéke a Zselicben vagy Belső-Somogyban még megtalálhatóaknak, ezáltal nem csak a fajkészlet lehet ott magasabb, de minden bizonnyal az egyedsürüség is. A kis területü élőhelyek fokozzák a fajok veszélyeztetettségét is, hiszen megfelelő ökológiai folyosó hiányában nincs lehetőség újratelepülésre. Ez utóbbi probléma föként az erdei fajokra vonatkozik, a nedvességigényes fajok esetében ugyanis a Deseda-patak mente megfelelő zöldfolyosóként szolgál. A domborzati adottságok és a területnagyságbeli különbség hozadéka az is, hogy egyes jelentős élőhelytípusok (bükkösök, homoki gyepek) - és a hozzájuk kötődő specialista rovarfajok - teljesen hiányoznak a Deseda-víztározó környékéről, míg a vizsgált tájvédelmi körzetekben megvannak. Mindemellett fontos megjegyezni, hogy a kutatások óta eltelt közel 30 évben sajnálatos módon a Zselic és Belső-Somogy lepkefaunája is bizonyosan jelentősen szegényedett. Ezért összességében elmondható, hogy a víztározó környezetében még megtalálható természeti értékek, bár erősen veszélyeztetettek, kistáji szinten igen jelentősek.

\section{Köszönetnyilvánítás}

A szerző köszönetét fejezi ki a szakmai segítségnyújtásért, a hasznos tanácsokért, továbbá a terepi munkában nyújtott segítségért Dr. Ábrahám Leventének, Dr. Kondorosy Elődnek, Dr. Juhász Magdolnának, Körtési Gábornak, Schmidt Andrásnak, Polovitzer Rékának és Győri Gabriellának. 
1. táblázat. A kimutatott fajok összesitett táblázata.

\begin{tabular}{|c|c|c|c|c|c|c|c|c|c|c|c|}
\hline Faj \ Lelőhely & $\begin{array}{c}1 \\
\text { MVB }\end{array}$ & $\begin{array}{c}2 \\
\text { MGT }\end{array}$ & $\begin{array}{c}3 \\
M G\end{array}$ & $\begin{array}{c}4 \\
\mathrm{AM}\end{array}$ & $\begin{array}{c}5 \\
S D\end{array}$ & $\begin{array}{c}6 \\
\mathrm{SH}\end{array}$ & $\begin{array}{c}7 \\
\text { KSZ }\end{array}$ & $\begin{array}{c}8 \\
K K\end{array}$ & $\begin{array}{c}9 \\
\text { TD }\end{array}$ & $\begin{array}{l}\text { Állatföld- } \\
\text { rajzi } \\
\text { beosztás }\end{array}$ & $\begin{array}{l}\text { Ökológiai } \\
\text { beosztás }\end{array}$ \\
\hline \multicolumn{12}{|l|}{ Microlepidoptera } \\
\hline Apoda limacodes & $\mathrm{O}$ & $\mathrm{O}$ & 0 & & 0 & 0 & & 0 & 0 & & \\
\hline Triodia sylvina & & & & & & & & 0 & 0 & & \\
\hline $\begin{array}{l}\text { Phragmataecia } \\
\text { castaneae }\end{array}$ & $\mathrm{O}$ & & & & $\mathrm{O}$ & & & & $\mathrm{O}$ & & \\
\hline Zeuzera pyrina & & & & & 0 & & & & & & \\
\hline Cossus cossus & & & $\mathrm{O}$ & & & & & & $\mathrm{O}$ & & \\
\hline \multicolumn{12}{|l|}{$\begin{array}{l}\text { Macrolepidoptera } \\
\text { / Heterocera }\end{array}$} \\
\hline \multicolumn{12}{|l|}{ Lasiocampidae } \\
\hline $\begin{array}{l}\text { Malacosoma } \\
\text { neustria }\end{array}$ & & & & & $\mathrm{O}$ & $\mathrm{O}$ & & & & Euroszibériai & Silvicol \\
\hline $\begin{array}{l}\text { Poecilocampa } \\
\text { populi }\end{array}$ & & & & & $\mathrm{O}$ & & & & & Euroszibériai & Nemorális \\
\hline $\begin{array}{l}\text { Lasiocampa } \\
\text { quercus }\end{array}$ & & & & $\mathrm{O}$ & & $\mathrm{O}$ & & & & Euroszibériai & Silvicol \\
\hline Macrothylacia rubi & & & $\mathrm{O}$ & & 0 & & & & & Euroszibériai & Euryök \\
\hline Eutrix potatoria & 0 & 0 & 0 & & & 0 & & 0 & 0 & Euroszibériai & Arundifil \\
\hline $\begin{array}{l}\text { Gastropacha } \\
\text { populifolia }\end{array}$ & & & & O & & & & & & Euroszibériai & Nyár faj \\
\hline $\begin{array}{l}\text { Gastropacha } \\
\text { quercifolia }\end{array}$ & & & & & & & & & 0 & Euroszibériai & Quercetális \\
\hline Odonestis pruni & $\mathrm{O}$ & & $\mathrm{O}$ & & & & & $\mathrm{O}$ & $\mathrm{O}$ & Euroszibériai & Silvicol \\
\hline \multicolumn{12}{|l|}{ Sphingidae } \\
\hline Hyloicus pinastri & & & 0 & 0 & 0 & 0 & 0 & & 0 & Euroszibériai & Pinetális \\
\hline $\begin{array}{l}\text { Smerinthus ocel- } \\
\text { latus }\end{array}$ & & & & & & & & & $\mathrm{O}$ & Euroszibériai & Nyár-füz faj \\
\hline Laothoe populi & $\mathrm{O}$ & & & & & $\mathrm{O}$ & & $\mathrm{O}$ & $\mathrm{O}$ & Euroszibériai & Nyár faj \\
\hline Agrius convulvuli & & & & 0 & & & & & & Vándor & Vándor \\
\hline Sphinx ligustri & & 0 & & & & & & & $\mathrm{O}$ & Euroszibériai & Silvicol \\
\hline $\begin{array}{l}\text { Deilephila elphe- } \\
\text { nor }\end{array}$ & & & & $\mathrm{O}$ & & & $\mathrm{O}$ & & $\mathrm{O}$ & Euroszibériai & Silvicol \\
\hline $\begin{array}{l}\text { Deilephila porcel- } \\
\text { lus }\end{array}$ & & & & $\mathrm{O}$ & & & O & & $\mathrm{O}$ & Euroszibériai & Euryök \\
\hline $\begin{array}{l}\text { Macroglossum } \\
\text { stellatarum }\end{array}$ & & & & 0 & & & $\mathrm{O}$ & 0 & 0 & Euroszibériai & Euryök \\
\hline Hyles euphorbiae & & & & & & & $\mathrm{O}$ & & & $\begin{array}{l}\text { Holomediter- } \\
\text { rán }\end{array}$ & Sztyepp faj \\
\hline Mimas tiliae & & & & & 0 & $\mathrm{O}$ & & & $\mathrm{O}$ & Euroszibériai & Silvicol \\
\hline \multicolumn{12}{|l|}{ Saturnidae } \\
\hline $\begin{array}{l}\text { Antherea yama- } \\
\text { mai }\end{array}$ & & 0 & $\mathrm{O}$ & 0 & 0 & 0 & $\mathrm{O}$ & 0 & 0 & $\begin{array}{l}\text { Pacifikus- } \\
\text { mandzsúriai }\end{array}$ & Quercetális \\
\hline Saturnia pyri & & & & & & $\mathrm{O}$ & & & & $\begin{array}{l}\text { Holomediter- } \\
\text { rán }\end{array}$ & Silvicol \\
\hline \multicolumn{12}{|l|}{ Drepanidae } \\
\hline Cilix glaucata & & & & & & & $\mathrm{O}$ & & & $\begin{array}{l}\text { Holomediter- } \\
\text { rán-iráni }\end{array}$ & Quercetális \\
\hline Drepana curvatula & & & & & & & & & $\mathrm{O}$ & Szibériai & Éger faj \\
\hline Drepana falcataria & & & 0 & 0 & & & 0 & & & Euroszibériai & Nemorális \\
\hline Sabra harpagula & & & & & & & & & 0 & Euroszibériai & Nemorális \\
\hline Watsonalla binaria & & $\mathrm{O}$ & $\mathrm{O}$ & $\mathrm{O}$ & $\mathrm{O}$ & $\mathrm{O}$ & & & & $\begin{array}{l}\text { Holomediter- } \\
\text { rán }\end{array}$ & Quercetális \\
\hline
\end{tabular}




\begin{tabular}{|c|c|c|c|c|c|c|c|c|c|c|c|}
\hline Faj \ Lelöhely & $\begin{array}{c}1 \\
\text { MVB }\end{array}$ & $\begin{array}{c}2 \\
\text { MGT }\end{array}$ & $\begin{array}{c}3 \\
\text { MG }\end{array}$ & $\begin{array}{c}4 \\
\text { AM }\end{array}$ & $\begin{array}{c}5 \\
\text { SD }\end{array}$ & $\begin{array}{l}6 \\
\text { SH }\end{array}$ & $\begin{array}{c}7 \\
\text { KSZ }\end{array}$ & $\begin{array}{c}8 \\
\mathrm{KK}\end{array}$ & $\begin{array}{c}9 \\
\mathrm{TD}\end{array}$ & $\begin{array}{c}\text { Állatföld- } \\
\text { rajzi } \\
\text { beosztás }\end{array}$ & $\begin{array}{l}\text { Ökológiai } \\
\text { beosztás }\end{array}$ \\
\hline \multicolumn{12}{|l|}{ Thyatiridae } \\
\hline Thyatira batis & & & $\mathrm{O}$ & $\mathrm{O}$ & $\mathrm{O}$ & $\mathrm{O}$ & $\mathrm{O}$ & $\mathrm{O}$ & 0 & Euroszibériai & Silvicol \\
\hline Polyploca ridens & & & $\mathrm{O}$ & & & $\mathrm{O}$ & & & & Euroszibériai & Quercetális \\
\hline Asphalia ruficollis & & & $\mathrm{O}$ & & & $\mathrm{O}$ & & & & $\begin{array}{l}\text { Holomediter- } \\
\text { rán-iráni }\end{array}$ & \begin{tabular}{|l} 
Pubescen- \\
tális
\end{tabular} \\
\hline Tethea or & & & & $\mathrm{O}$ & 0 & 0 & 0 & & $\mathrm{O}$ & Euroszibériai & Nyár-füz faj \\
\hline Tethea ocularis & & & & & & & 0 & & 0 & Euroszibériai & Nyár-füz faj \\
\hline $\begin{array}{l}\text { Habrosyne pyri- } \\
\text { toides }\end{array}$ & & 0 & $\mathrm{O}$ & $\mathrm{O}$ & & O & & 0 & 0 & Euroszibériai & Silvicol \\
\hline $\begin{array}{l}\text { Cymatophorima } \\
\text { diluta }\end{array}$ & & & $\mathrm{O}$ & & $\mathrm{O}$ & & & & & $\begin{array}{l}\text { Holomediter- } \\
\text { rán }\end{array}$ & Quercetális \\
\hline \multicolumn{12}{|l|}{ Notodontidae } \\
\hline Cerura erminea & & & & & & & 0 & & & Euroszibériai & Nyár faj \\
\hline Gluphisia crenata & $\mathrm{O}$ & & $\mathrm{O}$ & & & & & & $\mathrm{O}$ & Sybilla & $\begin{array}{l}\text { Altoherbosa } \\
\text { faj }\end{array}$ \\
\hline Furcula furcula & & & & & & & & & $\mathrm{O}$ & Holarktikus & Láperdő faj \\
\hline $\begin{array}{l}\text { Notodonta drom- } \\
\text { edarius }\end{array}$ & & & & $\mathrm{O}$ & & & & & & Szibériai & Nyír-éger faj \\
\hline Notodonta ziczac & & & & & & 0 & & & & Euroszibériai & Nyár-füz faj \\
\hline Drymonia velitaris & 0 & & $\mathrm{O}$ & & $\mathrm{O}$ & & & & & \begin{tabular}{|l|} 
Pontomedi- \\
terrán-holo- \\
mediterrán
\end{tabular} & Quercetális \\
\hline $\begin{array}{l}\text { Drymonia oblit- } \\
\text { erata }\end{array}$ & & $\mathrm{O}$ & $\mathrm{O}$ & & $\mathrm{O}$ & & $\mathrm{O}$ & $\mathrm{O}$ & & Szibériai & Nemorális \\
\hline Drymonia querna & & 0 & $\mathrm{O}$ & & $\mathrm{O}$ & $\mathrm{O}$ & & $\mathrm{O}$ & $\mathrm{O}$ & $\begin{array}{l}\text { Holomediter- } \\
\text { rán }\end{array}$ & Quercetális \\
\hline $\begin{array}{l}\text { Drymonia rufi- } \\
\text { cornis }\end{array}$ & & $\mathrm{O}$ & $\mathrm{O}$ & & $\mathrm{O}$ & O & & O & & Európai & Quercetális \\
\hline $\begin{array}{l}\text { Drymonia } \\
\text { dodonea }\end{array}$ & & 0 & & & & & & & & Euroszibériai & Silvicol \\
\hline Spatalia argentina & & & $\mathrm{O}$ & $\mathrm{O}$ & $\mathrm{O}$ & $\mathrm{O}$ & & $\mathrm{O}$ & & $\begin{array}{l}\text { Holomediter- } \\
\text { rán }\end{array}$ & Quercetális \\
\hline Harpya milhauseri & & & & & $\mathrm{O}$ & $\mathrm{O}$ & & $\mathrm{O}$ & $\mathrm{O}$ & Európai & Quercetális \\
\hline $\begin{array}{l}\text { Pterostoma } \\
\text { palpina }\end{array}$ & & & $\mathrm{O}$ & & & & & & $\mathrm{O}$ & Euroszibériai & Silvicol \\
\hline Stauropus fagi & & $\mathrm{O}$ & & & 0 & $\mathrm{O}$ & 0 & 0 & & Euroszibériai & Nemorális \\
\hline Pheosia tremula & & & $\mathrm{O}$ & 0 & & & & & $\mathrm{O}$ & Euroszibériai & Nyár faj \\
\hline $\begin{array}{l}\text { Phalera bu- } \\
\text { cephala }\end{array}$ & & 0 & $\mathrm{O}$ & & $\mathrm{O}$ & $\mathrm{O}$ & & & & Euroszibériai & Nyár-füz faj \\
\hline Ptilodon cucullina & & 0 & $\mathrm{O}$ & $\mathrm{O}$ & $\mathrm{O}$ & $\mathrm{O}$ & $\mathrm{O}$ & $\mathrm{O}$ & $\mathrm{O}$ & Euroszibériai & Nemorális \\
\hline Ptilodon capucina & & 0 & $\mathrm{O}$ & & $\mathrm{O}$ & & $\mathrm{O}$ & & $\mathrm{O}$ & Euroszibériai & Nemorális \\
\hline $\begin{array}{l}\text { Ptilophora plu- } \\
\text { migera }\end{array}$ & & & & & 0 & & & & & Euroszibériai & Nemorális \\
\hline $\begin{array}{l}\text { Clostera anasto- } \\
\text { mosis }\end{array}$ & & & $\mathrm{O}$ & & & & & & & Euroszibériai & Nyár-füz faj \\
\hline Clostera curtula & & & & & $\mathrm{O}$ & & & & & Euroszibériai & Nyár-füz faj \\
\hline $\begin{array}{l}\text { Clostera anacho- } \\
\text { reta }\end{array}$ & & 0 & & & & & $\mathrm{O}$ & & $\mathrm{O}$ & Euroszibériai & Nyár-füz faj \\
\hline \multicolumn{12}{|l|}{ Lymantridae } \\
\hline Pentophera morio & & & & & & 0 & & 0 & 0 & $\begin{array}{l}\text { Pontomedi- } \\
\text { terrán }\end{array}$ & Sztyepp faj \\
\hline Orgyia antiqua & & $\mathrm{O}$ & $\mathrm{O}$ & & $\mathrm{O}$ & $\mathrm{O}$ & $\mathrm{O}$ & $\mathrm{O}$ & $\mathrm{O}$ & Euroszibériai & Quercetális \\
\hline Lymantria dispar & $\mathrm{O}$ & $\mathrm{O}$ & $\mathrm{O}$ & & $\mathrm{O}$ & $\mathrm{O}$ & $\mathrm{O}$ & $\mathrm{O}$ & $\mathrm{O}$ & Euroszibériai & Silvicol \\
\hline
\end{tabular}




\begin{tabular}{|c|c|c|c|c|c|c|c|c|c|c|c|}
\hline Faj \ Lelőhely & $\begin{array}{c}1 \\
\text { MVB }\end{array}$ & $\begin{array}{c}2 \\
\text { MGT }\end{array}$ & $\begin{array}{c}3 \\
\text { MG }\end{array}$ & $\begin{array}{c}4 \\
\text { AM }\end{array}$ & $\begin{array}{c}5 \\
S D\end{array}$ & $\begin{array}{c}6 \\
\mathrm{SH}\end{array}$ & $\begin{array}{c}7 \\
\text { KSZ }\end{array}$ & $\begin{array}{c}8 \\
\text { KK }\end{array}$ & $\begin{array}{c}9 \\
\text { TD }\end{array}$ & $\begin{array}{c}\text { Állatföld- } \\
\text { rajzi } \\
\text { beosztás }\end{array}$ & $\begin{array}{l}\text { Ökológiai } \\
\text { beosztás }\end{array}$ \\
\hline $\begin{array}{l}\text { Calliteara pudi- } \\
\text { bunda }\end{array}$ & & 0 & 0 & & & 0 & & & & Euroszibériai & Nemorális \\
\hline Arctornis I-nigrum & & & 0 & & $\mathrm{O}$ & $\mathrm{O}$ & 0 & $\mathrm{O}$ & & Euroszibériai & Nyár-füz faj \\
\hline $\begin{array}{l}\text { Sphrageidus } \\
\text { similis }\end{array}$ & $\mathrm{O}$ & $\mathrm{O}$ & $\mathrm{O}$ & $\mathrm{O}$ & $\mathrm{O}$ & $\mathrm{O}$ & $\mathrm{O}$ & 0 & & Euroszibériai & Láperdő faj \\
\hline \multicolumn{12}{|l|}{ Arctiidae } \\
\hline $\begin{array}{l}\text { Spilosoma lubrici- } \\
\text { pedum }\end{array}$ & & & $\mathrm{O}$ & $\mathrm{O}$ & & & 0 & & 0 & Euroszibériai & Euryök \\
\hline Hyphantria cunea & & & & & & & & & $\mathrm{O}$ & Nearktikus & Adventív \\
\hline Spilarctia lutea & 0 & 0 & $\mathrm{O}$ & & $\mathrm{O}$ & & & & & Euroszibériai & Euryök \\
\hline Diaphora mendica & & & $\mathrm{O}$ & & & & & & & Euroszibériai & Euryök \\
\hline $\begin{array}{l}\text { Phragmatobia } \\
\text { fuliginosa }\end{array}$ & 0 & & 0 & $\mathrm{O}$ & $\mathrm{O}$ & & 0 & $\mathrm{O}$ & 0 & Euroszibériai & Euryök \\
\hline Arctia caja & $\mathrm{O}$ & & $\mathrm{O}$ & & & & & & & Holarktikus & Sztyepp faj \\
\hline Diacrisia sannio & & & $\mathrm{O}$ & & $\mathrm{O}$ & & $\mathrm{O}$ & & & Euroszibériai & Mezofil \\
\hline $\begin{array}{l}\text { Euplagia quadri- } \\
\text { punctaria }\end{array}$ & & 0 & 0 & & & $\mathrm{O}$ & & & & Európai & Quercetális \\
\hline $\begin{array}{l}\text { Miltochrista mini- } \\
\text { ata }\end{array}$ & $\mathrm{O}$ & $\mathrm{O}$ & $\mathrm{O}$ & O & $\mathrm{O}$ & O & $\mathrm{O}$ & O & $\mathrm{O}$ & Euroszibériai & Nemorális \\
\hline Thumata senex & $\mathrm{O}$ & 0 & $\mathrm{O}$ & & & $\mathrm{O}$ & & & $\mathrm{O}$ & Euroszibériai & Láperdő faj \\
\hline Pelosia muscerda & 0 & 0 & $\mathrm{O}$ & $\mathrm{O}$ & 0 & & & & 0 & Euroszibériai & Láperdő faj \\
\hline Pelosia obtusa & & 0 & & & & & & $\mathrm{O}$ & $\mathrm{O}$ & Sybilla & Láperdő faj \\
\hline Lithosia quadra & 0 & 0 & $\mathrm{O}$ & $\mathrm{O}$ & $\mathrm{O}$ & $\mathrm{O}$ & & $\mathrm{O}$ & $\mathrm{O}$ & Euroszibériai & Zuzmóevő \\
\hline Eilema griseola & & 0 & $\mathrm{O}$ & $\mathrm{O}$ & $\mathrm{O}$ & $\mathrm{O}$ & & & & Szibériai & Láperdő faj \\
\hline Eilema depressa & & & 0 & & & & O & & & $\begin{array}{l}\text { Holomediter- } \\
\text { rán }\end{array}$ & Zuzmóevő \\
\hline Eilema lurideola & 0 & 0 & $\mathrm{O}$ & $\mathrm{O}$ & $\mathrm{O}$ & $\mathrm{O}$ & & 0 & $\mathrm{O}$ & Euroszibériai & Zuzmóevő \\
\hline Eilema caniola & & & & & & 0 & & & & \begin{tabular}{|l|}
$\begin{array}{l}\text { Holomediter- } \\
\text { rán }\end{array}$ \\
\end{tabular} & Zuzmóevő \\
\hline Eilema complana & & & 0 & & 0 & $\mathrm{O}$ & 0 & 0 & & \begin{tabular}{|l|}
$\begin{array}{l}\text { Holomediter- } \\
\text { rán }\end{array}$ \\
\end{tabular} & Zuzmóevő \\
\hline Wittia sororcula & & $\mathrm{O}$ & O & & $\mathrm{O}$ & $\mathrm{O}$ & 0 & $\mathrm{O}$ & 0 & $\begin{array}{l}\text { Holomediter- } \\
\text { rán }\end{array}$ & Zuzmóevő \\
\hline Amata phegea & 0 & $\mathrm{O}$ & $\mathrm{O}$ & & $\mathrm{O}$ & $\mathrm{O}$ & & & 0 & & \\
\hline \multicolumn{12}{|l|}{ Geometridae } \\
\hline $\begin{array}{l}\text { Alsophila aescu- } \\
\text { laria }\end{array}$ & & & & & & $\mathrm{O}$ & & & & Euroszibériai & Nemorális \\
\hline $\begin{array}{l}\text { Comibaena baju- } \\
\text { laria }\end{array}$ & & 0 & & & & & & & & $\begin{array}{l}\text { Európai-ho- } \\
\text { lomediterrán }\end{array}$ & Quercetális \\
\hline $\begin{array}{l}\text { Hemistola chryso- } \\
\text { phrasaria }\end{array}$ & & $\mathrm{O}$ & 0 & & 0 & 0 & & 0 & & Euroszibériai & Silvicol \\
\hline Jodis lactearia & $\mathrm{O}$ & 0 & & $\mathrm{O}$ & & $\mathrm{O}$ & 0 & & & Euroszibériai & Nemorális \\
\hline Chlorissa viridata & & & $\mathrm{O}$ & & & & & & & Euroszibériai & Lápréti faj \\
\hline Chlorissa cloraria & & & & & & & 0 & & & Euroszibériai & Mezofil \\
\hline $\begin{array}{l}\text { Hemithea aesti- } \\
\text { varia }\end{array}$ & & O & & & $\mathrm{O}$ & & & & & Euroszibériai & Nemorális \\
\hline Idaea muricata & & & $\mathrm{O}$ & & & & & & 0 & Euroszibériai & Lápréti faj \\
\hline Idaea rusticata & & 0 & 0 & & $\mathrm{O}$ & & & & $\mathrm{O}$ & $\begin{array}{l}\text { Holomediter- } \\
\text { rán }\end{array}$ & Silvicol \\
\hline Idaea inquinata & & & $\mathrm{O}$ & & & & & & & $\begin{array}{l}\text { Holomediter- } \\
\text { rán }\end{array}$ & Euryök \\
\hline Idaea politaria & & & & & & $\mathrm{O}$ & & $\mathrm{O}$ & 0 & \begin{tabular}{|l|} 
Pontomedi- \\
terrán
\end{tabular} & Sztyepp faj \\
\hline
\end{tabular}




\begin{tabular}{|c|c|c|c|c|c|c|c|c|c|c|c|}
\hline Faj \ Lelőhely & $\begin{array}{c}1 \\
\text { MVB }\end{array}$ & $\begin{array}{c}2 \\
\text { MGT }\end{array}$ & $\begin{array}{c}3 \\
\text { MG }\end{array}$ & $\begin{array}{c}4 \\
\text { AM }\end{array}$ & $\begin{array}{c}5 \\
\text { SD }\end{array}$ & $\begin{array}{l}6 \\
\text { SH }\end{array}$ & $\begin{array}{c}7 \\
\text { KSZ }\end{array}$ & $\begin{array}{c}8 \\
\mathrm{KK}\end{array}$ & $\begin{array}{c}9 \\
\text { TD }\end{array}$ & $\begin{array}{c}\text { Állatföld- } \\
\text { rajzi } \\
\text { beosztás }\end{array}$ & $\begin{array}{l}\text { Ökológiai } \\
\text { beosztás }\end{array}$ \\
\hline Idaea seriata & & & & & & & & $\mathrm{O}$ & 0 & $\begin{array}{l}\text { Holomediter- } \\
\text { rán }\end{array}$ & Euryök \\
\hline $\begin{array}{l}\text { Idaea subsericea- } \\
\text { ta }\end{array}$ & & & & & & $\mathrm{O}$ & 0 & $\mathrm{O}$ & 0 & \begin{tabular}{|l|}
$\begin{array}{l}\text { Pontomedi- } \\
\text { terrán }\end{array}$ \\
\end{tabular} & Sztyepp faj \\
\hline Idaea biselata & 0 & & & & $\mathrm{O}$ & $\mathrm{O}$ & & $\mathrm{O}$ & 0 & Euroszibériai & $\begin{array}{l}\text { Láprét-láper- } \\
\text { dei faj }\end{array}$ \\
\hline Idaea dimidiata & $\mathrm{O}$ & $\mathrm{O}$ & $\mathrm{O}$ & & $\mathrm{O}$ & $\mathrm{O}$ & & $\mathrm{O}$ & 0 & $\begin{array}{l}\begin{array}{l}\text { Holomediter- } \\
\text { rán }\end{array} \\
\end{array}$ & Euryök \\
\hline Idaea trigeminata & $\mathrm{O}$ & $\mathrm{O}$ & $\mathrm{O}$ & & $\mathrm{O}$ & & & & 0 & $\begin{array}{l}\text { Pontomedi- } \\
\text { terrán-holo- } \\
\text { mediterrán }\end{array}$ & Silvicol \\
\hline Idaea aversata & $\mathrm{O}$ & $\mathrm{O}$ & $\mathrm{O}$ & $\mathrm{O}$ & $\mathrm{O}$ & $\mathrm{O}$ & & $\mathrm{O}$ & $\mathrm{O}$ & $\begin{array}{l}\text { Holomediter- } \\
\text { rán }\end{array}$ & Silvicol \\
\hline Idaea degeneraria & & $\mathrm{O}$ & 0 & O & $\mathrm{O}$ & 0 & & & & $\begin{array}{l}\text { Pontomedi- } \\
\text { terrán }\end{array}$ & $\begin{array}{l}\text { Quercetális- } \\
\text { silvicol faj }\end{array}$ \\
\hline Idaea deversaria & & & $\mathrm{O}$ & & & $\mathrm{O}$ & & & & Euroszibériai & Sztyepp faj \\
\hline Idaea straminata & & & & $\mathrm{O}$ & & & & & & Euroszibériai & Silvicol \\
\hline Scopula immorata & & & & & & & $\mathrm{O}$ & & $\mathrm{O}$ & Euroszibériai & Euryök \\
\hline Scopula incanata & & $\mathrm{O}$ & $\mathrm{O}$ & & & & & & & $\begin{array}{l}\text { Holomediter- } \\
\text { rán-ponto- } \\
\text { mediterrán }\end{array}$ & Sztyepp faj \\
\hline $\begin{array}{l}\text { Scopula nigro- } \\
\text { punctata }\end{array}$ & & $\mathrm{O}$ & $\mathrm{O}$ & $\mathrm{O}$ & $\mathrm{O}$ & $\mathrm{O}$ & O & & & Euroszibériai & Mezofil \\
\hline Scopula virgulata & & & & & & & & & $\mathrm{O}$ & Euroszibériai & Mezofil \\
\hline $\begin{array}{l}\text { Scopula subpunc- } \\
\text { taria }\end{array}$ & & & $\mathrm{O}$ & & & & & & & Sybilla & Lápréti faj \\
\hline Scopula immutata & & & & & & $\mathrm{O}$ & 0 & & $\mathrm{O}$ & Euroszibériai & Lápréti faj \\
\hline $\begin{array}{l}\text { Scopula flacci- } \\
\text { daria }\end{array}$ & & & & & & & & & O & $\begin{array}{l}\begin{array}{l}\text { Holomediter- } \\
\text { rán }\end{array} \\
\end{array}$ & Sztyepp faj \\
\hline $\begin{array}{l}\text { Scopula rubigi- } \\
\text { nata }\end{array}$ & & & $\mathrm{O}$ & $\mathrm{O}$ & & & & & 0 & Euroszibériai & Euryök \\
\hline $\begin{array}{l}\text { Scopula floslac- } \\
\text { tata }\end{array}$ & & 0 & & & & & & & & Euroszibériai & Silvicol \\
\hline $\begin{array}{l}\text { Cyclophora an- } \\
\text { nularia }\end{array}$ & & 0 & $\mathrm{O}$ & $\mathrm{O}$ & $\mathrm{O}$ & $\mathrm{O}$ & $\mathrm{O}$ & $\mathrm{O}$ & 0 & $\begin{array}{l}\begin{array}{l}\text { Holomediter- } \\
\text { rán }\end{array} \\
\end{array}$ & Euryök \\
\hline $\begin{array}{l}\text { Cyclophora pen- } \\
\text { dularia }\end{array}$ & & & & & & $\mathrm{O}$ & & & 0 & Szibériai & Füz faj \\
\hline $\begin{array}{l}\text { Cyclophora quer- } \\
\text { cimontaria }\end{array}$ & & 0 & $\mathrm{O}$ & & $\mathrm{O}$ & $\mathrm{O}$ & & & 0 & \begin{tabular}{|l|}
$\begin{array}{l}\text { Holomediter- } \\
\text { rán }\end{array}$ \\
\end{tabular} & Quercetális \\
\hline $\begin{array}{l}\text { Cyclophora rufi- } \\
\text { ciliaria }\end{array}$ & & 0 & & $\mathrm{O}$ & & $\mathrm{O}$ & & & & $\begin{array}{l}\begin{array}{l}\text { Holomediter- } \\
\text { rán }\end{array} \\
\end{array}$ & Quercetális \\
\hline Cyclophora porata & & $\mathrm{O}$ & $\mathrm{O}$ & & & & & & & $\begin{array}{l}\text { Holomediter- } \\
\text { rán }\end{array}$ & Quercetális \\
\hline $\begin{array}{l}\text { Cyclophora punc- } \\
\text { taria }\end{array}$ & & $\mathrm{O}$ & $\mathrm{O}$ & & $\mathrm{O}$ & $\mathrm{O}$ & & & $\mathrm{O}$ & $\begin{array}{l}\text { Holomediter- } \\
\text { rán }\end{array}$ & Silvicol \\
\hline $\begin{array}{l}\text { Cyclophora lin- } \\
\text { earia }\end{array}$ & & & $\mathrm{O}$ & & $\mathrm{O}$ & $\mathrm{O}$ & & $\mathrm{O}$ & & Euroszibériai & Silvicol \\
\hline $\begin{array}{l}\text { Rhodometra } \\
\text { sacraria }\end{array}$ & & & & & O & & & & O & Holarktikus & Vándor \\
\hline Timandra comae & 0 & 0 & $\mathrm{O}$ & & $\mathrm{O}$ & $\mathrm{O}$ & 0 & $\mathrm{O}$ & $\mathrm{O}$ & Euroszibériai & Euryök \\
\hline Lythria purpuraria & & & & & & & & & $\mathrm{O}$ & $\begin{array}{l}\text { Holomediter- } \\
\text { rán }\end{array}$ & Sztyepp faj \\
\hline $\begin{array}{l}\text { Orthonama obsti- } \\
\text { pata }\end{array}$ & & & & & $\mathrm{O}$ & & & & & Holarktikus & Vándor \\
\hline
\end{tabular}




\begin{tabular}{|c|c|c|c|c|c|c|c|c|c|c|c|}
\hline Faj \ Lelőhely & $\begin{array}{c}1 \\
\text { MVB }\end{array}$ & $\begin{array}{c}2 \\
\text { MGT }\end{array}$ & $\begin{array}{c}3 \\
\text { MG }\end{array}$ & $\begin{array}{c}4 \\
\text { AM }\end{array}$ & $\begin{array}{c}5 \\
S D\end{array}$ & $\begin{array}{c}6 \\
\mathrm{SH}\end{array}$ & $\begin{array}{c}7 \\
\text { KSZ }\end{array}$ & $\begin{array}{c}8 \\
\text { KK }\end{array}$ & $\begin{array}{c}9 \\
\text { TD }\end{array}$ & $\begin{array}{c}\text { Állatföld- } \\
\text { rajzi } \\
\text { beosztás }\end{array}$ & $\begin{array}{l}\text { Ökológiai } \\
\text { beosztás }\end{array}$ \\
\hline $\begin{array}{l}\text { Phibalapteryx } \\
\text { virgata }\end{array}$ & & & & & & & 0 & & & Euroszibériai & Sztyepp faj \\
\hline $\begin{array}{l}\text { Xanthorhoe } \\
\text { quadrifasciata }\end{array}$ & & $\mathrm{O}$ & $\mathrm{O}$ & & & 0 & & & & Euroszibériai & Nemorális \\
\hline $\begin{array}{l}\text { Xanthorhoe des- } \\
\text { ignata }\end{array}$ & & & & & & $\mathrm{O}$ & & & & Euroszibériai & Láperdő faj \\
\hline $\begin{array}{l}\text { Xanthorhoe spadi- } \\
\text { cearia }\end{array}$ & & & & & $\mathrm{O}$ & & & $\mathrm{O}$ & $\mathrm{O}$ & Euroszibériai & Euryök \\
\hline $\begin{array}{l}\text { Xanthorhoe fer- } \\
\text { rugata }\end{array}$ & & $\mathrm{O}$ & $\mathrm{O}$ & $\mathrm{O}$ & $\mathrm{O}$ & & O & $\mathrm{O}$ & $\mathrm{O}$ & Euroszibériai & Euryök \\
\hline $\begin{array}{l}\text { Xanthorhoe fluc- } \\
\text { tuata }\end{array}$ & & 0 & & & $\mathrm{O}$ & & & & & Euroszibériai & Silvicol \\
\hline Catarhoe cuculata & & & & & & 0 & & & $\mathrm{O}$ & Euroszibériai & Silvicol \\
\hline Epirrhoe alternata & 0 & $\mathrm{O}$ & $\mathrm{O}$ & $\mathrm{O}$ & $\mathrm{O}$ & $\mathrm{O}$ & 0 & $\mathrm{O}$ & $\mathrm{O}$ & Euroszibériai & Euryök \\
\hline Epirrhoe galiata & $\mathrm{O}$ & & & & & & & $\mathrm{O}$ & & $\begin{array}{l}\text { Holomediter- } \\
\text { rán }\end{array}$ & Silvicol \\
\hline $\begin{array}{l}\text { Costaconvexa } \\
\text { polygrammata }\end{array}$ & & & & & & & $\mathrm{O}$ & & & Euroszibériai & Sztyepp faj \\
\hline $\begin{array}{l}\text { Camptogramma } \\
\text { bilineata }\end{array}$ & & & $\mathrm{O}$ & & & 0 & & $\mathrm{O}$ & $\mathrm{O}$ & Euroszibériai & Sztyep faj \\
\hline $\begin{array}{l}\text { Mesoleuca albicil- } \\
\text { lata }\end{array}$ & & & & & & $\mathrm{O}$ & & & & Szibériai & Láperdő faj \\
\hline Pelurga comitata & & & $\mathrm{O}$ & & $\mathrm{O}$ & & & $\mathrm{O}$ & $\mathrm{O}$ & Euroszibériai & Silvicol \\
\hline $\begin{array}{l}\text { Cosmorhoe ocel- } \\
\text { lata }\end{array}$ & O & & & & & & & & & Euroszibériai & Silvicol \\
\hline Eulithis pyraliata & & & & & $\mathrm{O}$ & & & & $\mathrm{O}$ & Euroszibériai & Mezofil \\
\hline $\begin{array}{l}\text { Ecliptopera si- } \\
\text { laceata }\end{array}$ & & 0 & $\mathrm{O}$ & O & 0 & $\mathrm{O}$ & & 0 & $\mathrm{O}$ & Euroszibériai & Nemorális \\
\hline $\begin{array}{l}\text { Chloroclysta } \\
\text { siterata }\end{array}$ & & & $\mathrm{O}$ & & $\mathrm{O}$ & $\mathrm{O}$ & & & & \begin{tabular}{|l|}
$\begin{array}{l}\text { Holomediter- } \\
\text { rán }\end{array}$ \\
\end{tabular} & Nyár-füz faj \\
\hline $\begin{array}{l}\text { Electrophaes } \\
\text { corylata }\end{array}$ & & 0 & & & & & & & & Euroszibériai & Nemorális \\
\hline $\begin{array}{l}\text { Colostygia pecti- } \\
\text { nataria }\end{array}$ & & 0 & 0 & O & & & & $\mathrm{O}$ & $\mathrm{O}$ & Szibériai & Láperdő faj \\
\hline Horisme corticata & & $\mathrm{O}$ & $\mathrm{O}$ & & & 0 & & & $\mathrm{O}$ & \begin{tabular}{|l|}
$\begin{array}{l}\text { Holomediter- } \\
\text { rán }\end{array}$ \\
\end{tabular} & Quercetális \\
\hline Horisme tersata & & & & 0 & $\mathrm{O}$ & $\mathrm{O}$ & $\mathrm{O}$ & & $\mathrm{O}$ & Euroszibériai & Quercetális \\
\hline $\begin{array}{l}\text { Melanthia procel- } \\
\text { lata }\end{array}$ & & 0 & 0 & $\mathrm{O}$ & & $\mathrm{O}$ & & & & Euroszibériai & Silvicol \\
\hline $\begin{array}{l}\text { Philereme trans- } \\
\text { versata }\end{array}$ & & & & & O & & & & & \begin{tabular}{|l|} 
Pontomedi- \\
terrán-holo- \\
mediterrán \\
\end{tabular} & Quercetális \\
\hline $\begin{array}{l}\text { Euphyia biangu- } \\
\text { lata }\end{array}$ & & & O & & 0 & $\mathrm{O}$ & & O & & Euroszibériai & \begin{tabular}{|l} 
Altoherbosa- \\
nemorális faj
\end{tabular} \\
\hline Epirrita dilutata & & & & & $\mathrm{O}$ & & & & & Holarktikus & Nemorális \\
\hline Perizoma affiniata & & 0 & $\mathrm{O}$ & $\mathrm{O}$ & & $\mathrm{O}$ & & & $\mathrm{O}$ & Európai & Szubalpin \\
\hline $\begin{array}{l}\text { Perizoma lugdu- } \\
\text { naria }\end{array}$ & & & & & & & 0 & & O & Szibériai & $\begin{array}{l}\text { Láprét-láper- } \\
\text { dei faj }\end{array}$ \\
\hline $\begin{array}{l}\text { Perizoma alche- } \\
\text { millata }\end{array}$ & & & & & & $\mathrm{O}$ & & & & Euroszibériai & Silvicol \\
\hline $\begin{array}{l}\text { Gymnoscelis } \\
\text { rufifasciata }\end{array}$ & & & & & & & & & $\mathrm{O}$ & Euroszibériai & Euryök \\
\hline Chloroclystis v-ata & & & & $\mathrm{O}$ & $\mathrm{O}$ & $\mathrm{O}$ & & $\mathrm{O}$ & $\mathrm{O}$ & Szibériai & Nemorális \\
\hline $\begin{array}{l}\text { Pasiphila rectan- } \\
\text { gulata }\end{array}$ & & & $\mathrm{O}$ & & & & & & & Euroszibériai & Silvicol \\
\hline
\end{tabular}




\begin{tabular}{|c|c|c|c|c|c|c|c|c|c|c|c|}
\hline Faj \ Lelöhely & $\begin{array}{c}1 \\
\text { MVB }\end{array}$ & $\begin{array}{c}2 \\
\text { MGT }\end{array}$ & $\begin{array}{c}3 \\
\text { MG }\end{array}$ & $\begin{array}{c}4 \\
\text { AM }\end{array}$ & $\begin{array}{c}5 \\
\text { SD } \\
\end{array}$ & $\begin{array}{c}6 \\
\mathrm{SH}\end{array}$ & $\begin{array}{c}7 \\
\text { KSZ }\end{array}$ & $\begin{array}{c}8 \\
\mathrm{KK}\end{array}$ & $\begin{array}{c}9 \\
\text { TD }\end{array}$ & $\begin{array}{c}\text { Állatföld- } \\
\text { rajzi } \\
\text { beosztás }\end{array}$ & $\begin{array}{l}\text { Ökológiai } \\
\text { beosztás }\end{array}$ \\
\hline $\begin{array}{l}\text { Eupithecia cen- } \\
\text { taureata }\end{array}$ & & & & & & $\mathrm{O}$ & & & 0 & $\begin{array}{l}\text { Holomediter- } \\
\text { rán-turkesz- } \\
\text { táni }\end{array}$ & Sztyepp faj \\
\hline \multicolumn{12}{|l|}{ Eupithecia sp. } \\
\hline $\begin{array}{l}\text { Eupithecia hawor- } \\
\text { thiata }\end{array}$ & & & & & & & & & 0 & Euroszibériai & Euryök \\
\hline Asthena albulata & & 0 & $\mathrm{O}$ & & & $\mathrm{O}$ & & $\mathrm{O}$ & & Euroszibériai & Nemorális \\
\hline $\begin{array}{l}\text { Hydrelia flammeo- } \\
\text { laria }\end{array}$ & & & $\mathrm{O}$ & & $\mathrm{O}$ & $\mathrm{O}$ & & $\mathrm{O}$ & & Szibériai & Láperdő faj \\
\hline Minoa murinata & & & & & & & 0 & & & Euroszibériai & Euryök \\
\hline $\begin{array}{l}\text { Pterapherapteryx } \\
\text { sexalata }\end{array}$ & & & & & $\mathrm{O}$ & & & & 0 & Euroszibériai & Láperdő faj \\
\hline Acasis viretata & & $\mathrm{O}$ & & & & $\mathrm{O}$ & & & & Euroszibériai & $\begin{array}{l}\text { Lápréti-láper- } \\
\text { dei faj }\end{array}$ \\
\hline $\begin{array}{l}\text { Abraxas grossu- } \\
\text { lariata }\end{array}$ & 0 & & & & & & & & & Euroszibériai & Silvicol \\
\hline $\begin{array}{l}\text { Lomaspilis mar- } \\
\text { ginata }\end{array}$ & 0 & & $\mathrm{O}$ & O & O & 0 & & & 0 & Euroszibériai & Nemorális \\
\hline Stegania cararia & & & & & $\mathrm{O}$ & & & & 0 & Sybilla & Nyár-füz faj \\
\hline Ligdia adustata & $\mathrm{O}$ & $\mathrm{O}$ & $\mathrm{O}$ & $\mathrm{O}$ & $\mathrm{O}$ & $\mathrm{O}$ & $\mathrm{O}$ & $\mathrm{O}$ & 0 & $\begin{array}{l}\text { Holomediter- } \\
\text { rán }\end{array}$ & Silvicol \\
\hline Macaria notata & 0 & $\mathrm{O}$ & $\mathrm{O}$ & $\mathrm{O}$ & & $\mathrm{O}$ & $\mathrm{O}$ & $\mathrm{O}$ & & Euroszibériai & Silvicol \\
\hline Macaria alternata & 0 & 0 & $\mathrm{O}$ & & 0 & $\mathrm{O}$ & 0 & $\mathrm{O}$ & 0 & Euroszibériai & Nemorális \\
\hline Macaria liturata & & & $\mathrm{O}$ & 0 & $\mathrm{O}$ & & & & & Szibériai & Pinetális \\
\hline $\begin{array}{l}\text { Chiasmia clath- } \\
\text { rata }\end{array}$ & & & & & & & & & 0 & Euroszibériai & Euryök \\
\hline $\begin{array}{l}\text { Tephrina aren- } \\
\text { acearia }\end{array}$ & & & & $\mathrm{O}$ & & & & & 0 & Euroszibériai & Euryök \\
\hline $\begin{array}{l}\text { Cepphis adve- } \\
\text { naria }\end{array}$ & & & & & & $\mathrm{O}$ & & & & Euroszibériai & Láperdő faj \\
\hline $\begin{array}{l}\text { Plagodis pulver- } \\
\text { aria }\end{array}$ & & 0 & $\mathrm{O}$ & & $\mathrm{O}$ & & & $\mathrm{O}$ & & Euroszibériai & Silvicol \\
\hline $\begin{array}{l}\text { Plagodis dola- } \\
\text { braria }\end{array}$ & & $\mathrm{O}$ & $\mathrm{O}$ & & O & $\mathrm{O}$ & & O & 0 & Euroszibériai & Silvicol \\
\hline $\begin{array}{l}\text { Opisthograptis } \\
\text { luteolata }\end{array}$ & & 0 & $\mathrm{O}$ & & & & O & & 0 & Euroszibériai & Silvicol \\
\hline $\begin{array}{l}\text { Pseudopanthera } \\
\text { macularia }\end{array}$ & & & $\mathrm{O}$ & & $\mathrm{O}$ & $\mathrm{O}$ & & $\mathrm{O}$ & 0 & Euroszibériai & Euryök \\
\hline $\begin{array}{l}\text { Ennomos autum- } \\
\text { naria }\end{array}$ & & 0 & $\mathrm{O}$ & & $\mathrm{O}$ & & & & & Holarktikus & Silvicol \\
\hline $\begin{array}{l}\text { Ennomos querci- } \\
\text { naria }\end{array}$ & & & & & & & & $\mathrm{O}$ & & $\begin{array}{l}\text { Holomediter- } \\
\text { rán }\end{array}$ & Quercetális \\
\hline $\begin{array}{l}\text { Ennomos fuscan- } \\
\text { taria }\end{array}$ & & & $\mathrm{O}$ & & & & & & 0 & $\begin{array}{l}\text { Holomediter- } \\
\text { rán }\end{array}$ & Quercetális \\
\hline Ennomos erosaria & & & $\mathrm{O}$ & & $\mathrm{O}$ & $\mathrm{O}$ & & & $\mathrm{O}$ & \begin{tabular}{|l|}
$\begin{array}{l}\text { Holomediter- } \\
\text { rán }\end{array}$ \\
\end{tabular} & Quercetális \\
\hline Selenia dentaria & & 0 & & & & & & & & Euroszibériai & Silvicol \\
\hline Selenia lunularia & & 0 & & & $\mathrm{O}$ & & & & & $\begin{array}{l}\text { Holomediter- } \\
\text { rán }\end{array}$ & Silvicol \\
\hline $\begin{array}{l}\text { Selenia tetralu- } \\
\text { naria }\end{array}$ & & 0 & $\mathrm{O}$ & & $\mathrm{O}$ & $\mathrm{O}$ & & $\mathrm{O}$ & & Euroszibériai & Nemorális \\
\hline $\begin{array}{l}\text { Artiora evony- } \\
\text { maria }\end{array}$ & & & $\mathrm{O}$ & & & $\mathrm{O}$ & & & 0 & $\begin{array}{l}\text { Holomediter- } \\
\text { rán }\end{array}$ & Silvicol \\
\hline $\begin{array}{l}\text { Crocallis elin- } \\
\text { guaria }\end{array}$ & & & $\mathrm{O}$ & & & & & & & Euroszibériai & Silvicol \\
\hline
\end{tabular}




\begin{tabular}{|c|c|c|c|c|c|c|c|c|c|c|c|}
\hline Faj \ Lelőhely & $\begin{array}{c}1 \\
\text { MVB }\end{array}$ & $\stackrel{2}{\text { MGT }}$ & $\begin{array}{c}3 \\
\text { MG }\end{array}$ & $\begin{array}{c}4 \\
\text { AM }\end{array}$ & $\begin{array}{c}5 \\
S D\end{array}$ & $\begin{array}{c}6 \\
\mathrm{SH}\end{array}$ & $\begin{array}{c}7 \\
\text { KSZ }\end{array}$ & $\begin{array}{c}8 \\
\text { KK }\end{array}$ & $\begin{array}{c}9 \\
\text { TD }\end{array}$ & $\begin{array}{c}\text { Állatföld- } \\
\text { rajzi } \\
\text { beosztás }\end{array}$ & $\begin{array}{l}\text { Ökológiai } \\
\text { beosztás }\end{array}$ \\
\hline Colotois pennaria & & & & & & $\mathrm{O}$ & & & & \begin{tabular}{|l|}
$\begin{array}{l}\text { Holomediter- } \\
\text { rán }\end{array}$ \\
\end{tabular} & Quercetális \\
\hline $\begin{array}{l}\text { Angerona } \\
\text { prunaria }\end{array}$ & $\mathrm{O}$ & O & $\mathrm{O}$ & $\mathrm{O}$ & $\mathrm{O}$ & $\mathrm{O}$ & $\mathrm{O}$ & $\mathrm{O}$ & $\mathrm{O}$ & Euroszibériai & Silvicol \\
\hline Lycia hirtaria & & $\mathrm{O}$ & & & & $\mathrm{O}$ & & & & Euroszibériai & Silvicol \\
\hline $\begin{array}{l}\text { Apocheima pi- } \\
\text { losaria }\end{array}$ & & & $\mathrm{O}$ & & & $\mathrm{O}$ & & & & Euroszibériai & Silvicol \\
\hline $\begin{array}{l}\text { Apocheima hispi- } \\
\text { daria }\end{array}$ & & & $\mathrm{O}$ & & & $\mathrm{O}$ & & & & Euroszibériai & Silvicol \\
\hline Biston strataria & & & 0 & & & 0 & & & & \begin{tabular}{|l|}
$\begin{array}{l}\text { Holomediter- } \\
\text { rán }\end{array}$ \\
\end{tabular} & Silvicol \\
\hline Biston betularia & & & $\mathrm{O}$ & & $\mathrm{O}$ & & & & 0 & Euroszibériai & Euryök \\
\hline Erannis defoliaria & & & $\mathrm{O}$ & & & & & & $\mathrm{O}$ & \begin{tabular}{|l|}
$\begin{array}{l}\text { Holomediter- } \\
\text { rán }\end{array}$ \\
\end{tabular} & Quercetális \\
\hline $\begin{array}{l}\text { Agriopis margi- } \\
\text { naria }\end{array}$ & & & $\mathrm{O}$ & & & $\mathrm{O}$ & & & & \begin{tabular}{|l|}
$\begin{array}{l}\text { Holomediter- } \\
\text { rán }\end{array}$ \\
\end{tabular} & Silvicol \\
\hline $\begin{array}{l}\begin{array}{l}\text { Peribatodes } \\
\text { rhomboidaria }\end{array} \\
\end{array}$ & $\mathrm{O}$ & $\mathrm{O}$ & $\mathrm{O}$ & $\mathrm{O}$ & $\mathrm{O}$ & $\mathrm{O}$ & & $\mathrm{O}$ & $\mathrm{O}$ & Euroszibériai & Euryök \\
\hline Ascotis selenaria & $\mathrm{O}$ & & $\mathrm{O}$ & $\mathrm{O}$ & 0 & $\mathrm{O}$ & $\mathrm{O}$ & $\mathrm{O}$ & 0 & Euroszibériai & Euryök \\
\hline $\begin{array}{l}\text { Hypomecis robo- } \\
\text { raria }\end{array}$ & & O & & & O & $\mathrm{O}$ & $\mathrm{O}$ & $\mathrm{O}$ & $\mathrm{O}$ & Euroszibériai & Quercetális \\
\hline Hypomecis danieli & $\mathrm{O}$ & & $\mathrm{O}$ & & & & & & $\mathrm{O}$ & Európai & Quercetális \\
\hline $\begin{array}{l}\text { Hypomecis punc- } \\
\text { tinalis }\end{array}$ & & $\mathrm{O}$ & $\mathrm{O}$ & $\mathrm{O}$ & $\mathrm{O}$ & $\mathrm{O}$ & $\mathrm{O}$ & $\mathrm{O}$ & $\mathrm{O}$ & Euroszibériai & Silvicol \\
\hline $\begin{array}{l}\text { Ectropis crepus- } \\
\text { cularia }\end{array}$ & $\mathrm{O}$ & $\mathrm{O}$ & O & O & O & O & & O & O & Euroszibériai & Euryök \\
\hline $\begin{array}{l}\text { Aethealura } \\
\text { punctulata }\end{array}$ & $\mathrm{O}$ & $\mathrm{O}$ & $\mathrm{O}$ & & & & & & & Euroszibériai & Nyír-éger faj \\
\hline $\begin{array}{l}\text { Ematurga ato- } \\
\text { maria }\end{array}$ & & $\mathrm{O}$ & O & O & O & & O & O & O & Euroszibériai & Euryök \\
\hline $\begin{array}{l}\text { Lomographa } \\
\text { bimaculata }\end{array}$ & & $\mathrm{O}$ & O & & $\mathrm{O}$ & $\mathrm{O}$ & & $\mathrm{O}$ & & Euroszibériai & Silvicol \\
\hline $\begin{array}{l}\text { Lomographa } \\
\text { temerata }\end{array}$ & & & $\mathrm{O}$ & & & $\mathrm{O}$ & & & $\mathrm{O}$ & Euroszibériai & Silvicol \\
\hline $\begin{array}{l}\text { Cabera exanthe- } \\
\text { mata }\end{array}$ & & & & $\mathrm{O}$ & $\mathrm{O}$ & $\mathrm{O}$ & O & & $\mathrm{O}$ & Euroszibériai & Nyár-füz faj \\
\hline Cabera pusaria & $\mathrm{O}$ & & $\mathrm{O}$ & $\mathrm{O}$ & $\mathrm{O}$ & & $\mathrm{O}$ & & & \begin{tabular}{|l|} 
Euroszibériai \\
\end{tabular} & Láperdő faj \\
\hline $\begin{array}{l}\text { Campaea marga- } \\
\text { ritaria }\end{array}$ & & $\mathrm{O}$ & & & 0 & & & & O & $\begin{array}{l}\begin{array}{l}\text { Holomediter- } \\
\text { rán }\end{array} \\
\end{array}$ & Silvicol \\
\hline $\begin{array}{l}\text { Chariaspilates } \\
\text { formosaria }\end{array}$ & & & & & & & & & O & Sybilla & Láperdő faj \\
\hline Siona lineata & & & & & & & $\mathrm{O}$ & & & Euroszibériai & Mezofil \\
\hline \multicolumn{12}{|l|}{ Noctuidae } \\
\hline Rivula sericealis & $\mathrm{O}$ & $\mathrm{O}$ & $\mathrm{O}$ & $\mathrm{O}$ & $\mathrm{O}$ & $\mathrm{O}$ & $\mathrm{O}$ & $\mathrm{O}$ & $\mathrm{O}$ & Euroszibériai & Euryök \\
\hline $\begin{array}{l}\text { Parascotia fuligi- } \\
\text { naria }\end{array}$ & & $\mathrm{O}$ & & & & $\mathrm{O}$ & & & & Euroszibériai & Gombaevő \\
\hline $\begin{array}{l}\text { Trisateles emor- } \\
\text { tualis }\end{array}$ & & $\mathrm{O}$ & $\mathrm{O}$ & $\mathrm{O}$ & $\mathrm{O}$ & $\mathrm{O}$ & & $\mathrm{O}$ & & Szibériai & Nemorális \\
\hline Laspeyria flexula & $\mathrm{O}$ & $\mathrm{O}$ & $\mathrm{O}$ & $\mathrm{O}$ & $\mathrm{O}$ & $\mathrm{O}$ & $\mathrm{O}$ & & $\mathrm{O}$ & Szibériai & Zuzmóevő \\
\hline $\begin{array}{l}\text { Hypenodes humi- } \\
\text { dalis }\end{array}$ & & $\mathrm{O}$ & & & & $\mathrm{O}$ & & & & Szibériai & $\begin{array}{l}\text { Láprét-láper- } \\
\text { dei faj } \\
\end{array}$ \\
\hline $\begin{array}{l}\text { Schrankia cos- } \\
\text { taestrigalis }\end{array}$ & & O & O & O & O & & & & & Szibériai & $\begin{array}{l}\text { Láprét-láper- } \\
\text { dei faj }\end{array}$ \\
\hline Paracolax tristalis & 0 & $\mathrm{O}$ & $\mathrm{O}$ & & $\mathrm{O}$ & 0 & & 0 & 0 & Euroszibériai & Euryök \\
\hline
\end{tabular}




\begin{tabular}{|c|c|c|c|c|c|c|c|c|c|c|c|}
\hline Faj \ Lelőhely & $\stackrel{1}{M V B}$ & $\stackrel{2}{\text { MGT }}$ & $\begin{array}{c}3 \\
\text { MG }\end{array}$ & $\begin{array}{c}4 \\
\mathrm{AM}\end{array}$ & $\begin{array}{c}5 \\
\text { SD }\end{array}$ & $\begin{array}{c}6 \\
\text { SH }\end{array}$ & $\begin{array}{c}7 \\
\mathrm{KSZ}\end{array}$ & $\stackrel{8}{\mathrm{KK}}$ & $\begin{array}{c}9 \\
\text { TD }\end{array}$ & $\begin{array}{l}\text { Állatföld- } \\
\text { rajzi } \\
\text { beosztás }\end{array}$ & $\begin{array}{l}\text { Ökológiai } \\
\text { beosztás }\end{array}$ \\
\hline Idia calvaria & & & & & $\mathrm{O}$ & & & $\mathrm{O}$ & & Euroszibériai & Gombaevő \\
\hline $\begin{array}{l}\text { Macrochilo cribru- } \\
\text { malis }\end{array}$ & & $\mathrm{O}$ & & & $\mathrm{O}$ & & & & $\mathrm{O}$ & Szibériai & Arundifil \\
\hline $\begin{array}{l}\text { Herminia tarsicri- } \\
\text { nalis }\end{array}$ & 0 & 0 & $\mathrm{O}$ & 0 & $\mathrm{O}$ & $\mathrm{O}$ & 0 & $\mathrm{O}$ & 0 & Euroszibériai & Avarevő \\
\hline $\begin{array}{l}\text { Herminia tarsipen- } \\
\text { nalis }\end{array}$ & & 0 & $\mathrm{O}$ & 0 & $\mathrm{O}$ & & 0 & & 0 & Euroszibériai & Avarevő \\
\hline Herminia grisealis & 0 & $\mathrm{O}$ & $\mathrm{O}$ & $\mathrm{O}$ & $\mathrm{O}$ & $\mathrm{O}$ & & & $\mathrm{O}$ & Euroszibériai & Euryök \\
\hline $\begin{array}{l}\text { Polypogon ten- } \\
\text { tacularia }\end{array}$ & & & & $\mathrm{O}$ & & $\mathrm{O}$ & $\mathrm{O}$ & O & & Euroszibériai & Euryök \\
\hline $\begin{array}{l}\text { Polypogon gry- } \\
\text { phalis }\end{array}$ & & & & & & & $\mathrm{O}$ & & & Sybilla & Láperdő faj \\
\hline $\begin{array}{l}\text { Zanchlognatha } \\
\text { lunalis }\end{array}$ & $\mathrm{O}$ & 0 & $\mathrm{O}$ & & $\mathrm{O}$ & $\mathrm{O}$ & & $\mathrm{O}$ & 0 & Euroszibériai & Avarevő \\
\hline $\begin{array}{l}\text { Pechipogo strigi- } \\
\text { lata }\end{array}$ & & 0 & $\mathrm{O}$ & $\mathrm{O}$ & & $\mathrm{O}$ & & & 0 & Euroszibériai & Avarevő \\
\hline $\begin{array}{l}\text { Hypena pro- } \\
\text { boscidalis }\end{array}$ & & & $\mathrm{O}$ & $\mathrm{O}$ & $\mathrm{O}$ & $\mathrm{O}$ & & $\mathrm{O}$ & O & Euroszibériai & Euryök \\
\hline Hypena rostralis & & $\mathrm{O}$ & & $\mathrm{O}$ & $\mathrm{O}$ & & & & 0 & Euroszibériai & Euryök \\
\hline $\begin{array}{l}\text { Scoliopteryx } \\
\text { libatryx }\end{array}$ & & & & & $\mathrm{O}$ & & & & & Euroszibériai & Nyár-füz faj \\
\hline $\begin{array}{l}\text { Catocala nymph- } \\
\text { agoga }\end{array}$ & & & $\mathrm{O}$ & & $\mathrm{O}$ & & & & & $\begin{array}{l}\text { Holomediter- } \\
\text { rán-iráni }\end{array}$ & Quercetális \\
\hline $\begin{array}{l}\text { Catocala hyme- } \\
\text { naea }\end{array}$ & 0 & & & & & & 0 & & 0 & \begin{tabular}{|l}
$\begin{array}{l}\text { Pontomedi- } \\
\text { terrán }\end{array}$ \\
\end{tabular} & \begin{tabular}{|l|} 
Mezofil, \\
galagonya faj
\end{tabular} \\
\hline $\begin{array}{l}\text { Catocala prom- } \\
\text { issa }\end{array}$ & & 0 & $\mathrm{O}$ & & & & & & & $\begin{array}{l}\text { Holomediter- } \\
\text { rán }\end{array}$ & Quercetális \\
\hline Catocala electa & & & & $\mathrm{O}$ & & & & & & Szibériai & Füz-nyár faj \\
\hline Catocala nupta & & & & & & $\mathrm{O}$ & & & $\mathrm{O}$ & Euroszibériai & Nyár faj \\
\hline Catocala elocata & & & & & & & & & $\mathrm{O}$ & Euroszibériai & Nyár faj \\
\hline Euclidia glyphica & & & $\mathrm{O}$ & & $\mathrm{O}$ & & $\mathrm{O}$ & & $\mathrm{O}$ & Euroszibériai & Sztyepp faj \\
\hline Minucia lunaris & & & $\mathrm{O}$ & & $\mathrm{O}$ & & & & & $\begin{array}{l}\text { Holomediter- } \\
\text { rán }\end{array}$ & Quercetális \\
\hline Dysgonia algira & & & $\mathrm{O}$ & & & & O & & & $\begin{array}{l}\text { Holomediter- } \\
\text { rán-iráni }\end{array}$ & Quercetális \\
\hline $\begin{array}{l}\text { Pseudoips prasi- } \\
\text { nana }\end{array}$ & & 0 & $\mathrm{O}$ & 0 & $\mathrm{O}$ & $\mathrm{O}$ & O & $\mathrm{O}$ & 0 & Euroszibériai & Silvicol \\
\hline Eutelia adulatrix & & & & & & & & & 0 & $\begin{array}{l}\text { Holomediter- } \\
\text { rán-turkesz- } \\
\text { táni }\end{array}$ & $\begin{array}{l}\text { Pubescen- } \\
\text { tális }\end{array}$ \\
\hline Meganola strigula & $\mathrm{O}$ & $\mathrm{O}$ & $\mathrm{O}$ & $\mathrm{O}$ & $\mathrm{O}$ & $\mathrm{O}$ & & & & $\begin{array}{l}\text { Holomediter- } \\
\text { rán }\end{array}$ & Quercetális \\
\hline Meganola albula & & & $\mathrm{O}$ & $\mathrm{O}$ & $\mathrm{O}$ & $\mathrm{O}$ & $\mathrm{O}$ & $\mathrm{O}$ & 0 & Szibériai & Láperdő faj \\
\hline Nola cristatula & & $\mathrm{O}$ & & & & & & $\mathrm{O}$ & & Szibériai & Láperdő faj \\
\hline Nola confusalis & & $\mathrm{O}$ & & $\mathrm{O}$ & $\mathrm{O}$ & $\mathrm{O}$ & & & & Euroszibériai & Nemorális \\
\hline Nola aerugula & & & $\mathrm{O}$ & $\mathrm{O}$ & $\mathrm{O}$ & $\mathrm{O}$ & $\mathrm{O}$ & & $\mathrm{O}$ & Euroszibériai & Silvicol \\
\hline Nola chlamitulalis & & & & & & & $\mathrm{O}$ & $\mathrm{O}$ & 0 & $\begin{array}{l}\text { Holomediter- } \\
\text { rán-iráni }\end{array}$ & Silvicol \\
\hline Ealias clorana & & & & $\mathrm{O}$ & & $\mathrm{O}$ & $\mathrm{O}$ & & $\mathrm{O}$ & Euroszibériai & Füz faj \\
\hline Nycteola asiatica & & & & & & $\mathrm{O}$ & $\mathrm{O}$ & & & Szibériai & Nyár-füz faj \\
\hline Abrostola triplasia & & & O & $\mathrm{O}$ & 0 & & $\mathrm{O}$ & $\mathrm{O}$ & $\mathrm{O}$ & Euroszibériai & $\begin{array}{l}\text { Altoherbosa } \\
\text { faj }\end{array}$ \\
\hline $\begin{array}{l}\text { Macdunnoughia } \\
\text { confusa }\end{array}$ & & & $\mathrm{O}$ & & $\mathrm{O}$ & & & & $\mathrm{O}$ & Euroszibériai & Euryök \\
\hline
\end{tabular}




\begin{tabular}{|c|c|c|c|c|c|c|c|c|c|c|c|}
\hline Faj \ Lelőhely & $\begin{array}{c}1 \\
\text { MVB }\end{array}$ & $\stackrel{2}{\text { MGT }}$ & $\begin{array}{c}3 \\
\text { MG }\end{array}$ & $\begin{array}{c}4 \\
\text { AM }\end{array}$ & $\begin{array}{c}5 \\
\text { SD }\end{array}$ & $\begin{array}{c}6 \\
\text { SH }\end{array}$ & $\begin{array}{c}7 \\
\text { KSZ }\end{array}$ & $\begin{array}{c}8 \\
K K\end{array}$ & $\begin{array}{c}9 \\
\text { TD }\end{array}$ & $\begin{array}{c}\text { Állatföld- } \\
\text { rajzi } \\
\text { beosztás }\end{array}$ & $\begin{array}{l}\text { Ökológiai } \\
\text { beosztás }\end{array}$ \\
\hline $\begin{array}{l}\text { Diachrysia steno- } \\
\text { chrysis }\end{array}$ & & & & & & $\mathrm{O}$ & $\mathrm{O}$ & & O & Euroszibériai & Euryök \\
\hline $\begin{array}{l}\text { Diachrysia chrys- } \\
\text { tis }\end{array}$ & & & 0 & & & & & & $\mathrm{O}$ & Euroszibériai & Euryök \\
\hline $\begin{array}{l}\text { Autographa } \\
\text { gamma }\end{array}$ & & & & O & $\mathrm{O}$ & $\mathrm{O}$ & O & & 0 & Vándor & Vándor \\
\hline Deltote bankiana & & & & & & $\mathrm{O}$ & $\mathrm{O}$ & & 0 & Szibériai & Lápréti faj \\
\hline $\begin{array}{l}\text { Protodeltote } \\
\text { pygarga }\end{array}$ & & & O & O & O & O & $\mathrm{O}$ & $\mathrm{O}$ & O & Euroszibériai & Euryök \\
\hline Acontia trabealis & & & 0 & $\mathrm{O}$ & & & $\mathrm{O}$ & 0 & 0 & Euroszibériai & Euryök \\
\hline Aedia funesta & & & & & $\mathrm{O}$ & & & & $\mathrm{O}$ & $\begin{array}{l}\text { Holomediter- } \\
\text { rán }\end{array}$ & Lejtősztyepp \\
\hline Aedia leucomelas & & & & & & & $\mathrm{O}$ & $\mathrm{O}$ & & $\begin{array}{l}\begin{array}{l}\text { Holomediter- } \\
\text { rán }\end{array} \\
\end{array}$ & Expanzív \\
\hline Colocasia coryli & & $\mathrm{O}$ & $\mathrm{O}$ & & $\mathrm{O}$ & $\mathrm{O}$ & $\mathrm{O}$ & $\mathrm{O}$ & $\mathrm{O}$ & \begin{tabular}{|l|} 
Euroszibériai \\
\end{tabular} & Nemorális \\
\hline Moma alpinum & & 0 & & & O & $\mathrm{O}$ & & & & $\begin{array}{l}\text { Holomediter- } \\
\text { rán }\end{array}$ & Quercetális \\
\hline $\begin{array}{l}\text { Craniophora } \\
\text { ligustri }\end{array}$ & & & $\mathrm{O}$ & $\mathrm{O}$ & $\mathrm{O}$ & $\mathrm{O}$ & $\mathrm{O}$ & $\mathrm{O}$ & & Euroszibériai & Silvicol \\
\hline Acronicta alni & & & & & & & & & $\mathrm{O}$ & Szibériai & Éger faj \\
\hline Acronicta rumicis & & & $\mathrm{O}$ & & 0 & & & 0 & & Euroszibériai & Euryök \\
\hline Acronicta aceris & & & & & $\mathrm{O}$ & 0 & & & O & $\begin{array}{l}\text { Holomediter- } \\
\text { rán }\end{array}$ & Silvicol \\
\hline Acronicta leporina & & & & & & & & & $\mathrm{O}$ & Szibériai & Nyír-éger faj \\
\hline $\begin{array}{l}\text { Acronicta mega- } \\
\text { cephala }\end{array}$ & & & $\mathrm{O}$ & & & & & & $\mathrm{O}$ & Szibériai & Nyár-füz faj \\
\hline $\begin{array}{l}\text { Panemeria ten- } \\
\text { ebrata }\end{array}$ & & 0 & & & $\mathrm{O}$ & & & & & Ponto-Kaszpi & Mezofil \\
\hline Tyta luctuosa & & & & $\mathrm{O}$ & & & $\mathrm{O}$ & $\mathrm{O}$ & $\mathrm{O}$ & Euroszibériai & Sztyepp faj \\
\hline Calophasia lunula & & & & & & & & $\mathrm{O}$ & & Euroszibériai & Lejtösztyepp \\
\hline $\begin{array}{l}\text { Amphipyra } \\
\text { tragopogonis }\end{array}$ & $\mathrm{O}$ & & O & & $\mathrm{O}$ & 0 & & & & Szibériai & Silvicol \\
\hline $\begin{array}{l}\text { Amphipyra pyra- } \\
\text { midea }\end{array}$ & & $\mathrm{O}$ & O & O & O & O & & 0 & O & Szibériai & Silvicol \\
\hline $\begin{array}{l}\text { Amphipyra ber- } \\
\text { bera }\end{array}$ & & & & $\mathrm{O}$ & & & & & O & $\begin{array}{l}\text { Holomediter- } \\
\text { rán }\end{array}$ & Quercetális \\
\hline Amphipyra livida & & & & & & $\mathrm{O}$ & & & & $\begin{array}{l}\text { Holomediter- } \\
\text { rán }\end{array}$ & Quercetális \\
\hline Valeria oleagina & & & 0 & & & & & & & \begin{tabular}{|l|} 
Pontomedi- \\
terrán
\end{tabular} & Quercetális \\
\hline $\begin{array}{l}\text { Allophyles oxya- } \\
\text { canthae }\end{array}$ & & & 0 & & $\mathrm{O}$ & $\mathrm{O}$ & & & & Euroszibériai & Lejtősztyepp \\
\hline $\begin{array}{l}\text { Eucarta amethys- } \\
\text { tina }\end{array}$ & & & & & & & O & & & Sybilla & $\begin{array}{l}\text { Láprét-láper- } \\
\text { dei faj }\end{array}$ \\
\hline Eucarta virgo & & & 0 & & & & & 0 & O & Sybilla & $\begin{array}{l}\text { Láprét-láper- } \\
\text { dei faj }\end{array}$ \\
\hline Pyrrhia umbra & & & & & & & $\mathrm{O}$ & & & Euroszibériai & Silvicol \\
\hline Heliotis viriplaca & & & & & & & & & $\mathrm{O}$ & Euroszibériai & Vándor \\
\hline Heliotis adaucta & & & & & & $\mathrm{O}$ & & & 0 & Euroszibériai & Vándor \\
\hline $\begin{array}{l}\text { Helicoverpa ar- } \\
\text { migera }\end{array}$ & & & O & $\mathrm{O}$ & $\mathrm{O}$ & $\mathrm{O}$ & $\mathrm{O}$ & $\mathrm{O}$ & 0 & Vándor & Vándor \\
\hline Cryphia algae & & & & & & & $\mathrm{O}$ & & $\mathrm{O}$ & Euroszibériai & Zuzmóevő \\
\hline $\begin{array}{l}\text { Cryphia frauda- } \\
\text { tricula }\end{array}$ & & & & & & & & & $\mathrm{O}$ & $\begin{array}{l}\text { Holomediter- } \\
\text { rán }\end{array}$ & Psammofil \\
\hline
\end{tabular}




\begin{tabular}{|c|c|c|c|c|c|c|c|c|c|c|c|}
\hline Faj \ Lelőhely & $\begin{array}{c}1 \\
\text { MVB }\end{array}$ & $\stackrel{2}{\mathrm{MGT}}$ & $\begin{array}{c}3 \\
M G\end{array}$ & $\begin{array}{c}4 \\
\text { AM }\end{array}$ & $\begin{array}{c}5 \\
\text { SD }\end{array}$ & $\begin{array}{l}6 \\
\text { SH }\end{array}$ & $\begin{array}{c}7 \\
\text { KSZ }\end{array}$ & $\begin{array}{c}8 \\
\mathrm{KK}\end{array}$ & $\begin{array}{c}9 \\
\text { TD }\end{array}$ & $\begin{array}{c}\text { Állatföld- } \\
\text { rajzi } \\
\text { beosztás }\end{array}$ & $\begin{array}{l}\text { Ökológiai } \\
\text { beosztás }\end{array}$ \\
\hline $\begin{array}{l}\text { Pseudeustrotia } \\
\text { candidula }\end{array}$ & 0 & & & & & $\mathrm{O}$ & & & $\mathrm{O}$ & Szibériai & Euryök \\
\hline $\begin{array}{l}\text { Elaphria venus- } \\
\text { tula }\end{array}$ & & 0 & 0 & 0 & $\mathrm{O}$ & $\mathrm{O}$ & 0 & $\mathrm{O}$ & $\mathrm{O}$ & Euroszibériai & $\begin{array}{l}\text { Láprét-láper- } \\
\text { dei faj }\end{array}$ \\
\hline $\begin{array}{l}\text { Spodoptera } \\
\text { exigua }\end{array}$ & & & & & & $\mathrm{O}$ & 0 & & & Vándor & Vándor \\
\hline $\begin{array}{l}\text { Caradrina mor- } \\
\text { pheus }\end{array}$ & & $\mathrm{O}$ & 0 & & $\mathrm{O}$ & $\mathrm{O}$ & $\mathrm{O}$ & $\mathrm{O}$ & $\mathrm{O}$ & Euroszibériai & Euryök \\
\hline Caradrina kadenii & & & $\mathrm{O}$ & & $\mathrm{O}$ & & & & & Euroszibériai & Euryök \\
\hline Hoplodrina blanda & & $\mathrm{O}$ & $\mathrm{O}$ & & $\mathrm{O}$ & $\mathrm{O}$ & $\mathrm{O}$ & $\mathrm{O}$ & & $\begin{array}{l}\text { Holomediter- } \\
\text { rán }\end{array}$ & Silvicol \\
\hline $\begin{array}{l}\text { Hoplodrina octo- } \\
\text { genaria }\end{array}$ & & & & & $\mathrm{O}$ & & & $\mathrm{O}$ & $\mathrm{O}$ & $\begin{array}{l}\begin{array}{l}\text { Holomediter- } \\
\text { rán }\end{array} \\
\end{array}$ & Silvicol \\
\hline $\begin{array}{l}\text { Hoplodrina am- } \\
\text { bigua }\end{array}$ & 0 & & $\mathrm{O}$ & & $\mathrm{O}$ & $\mathrm{O}$ & & $\mathrm{O}$ & $\mathrm{O}$ & $\begin{array}{l}\text { Holomediter- } \\
\text { rán }\end{array}$ & Euryök \\
\hline Chilodes maritima & & & & & & & & & $\mathrm{O}$ & Euroszibériai & Arundifil \\
\hline $\begin{array}{l}\text { Charanyca tri- } \\
\text { grammica }\end{array}$ & & 0 & 0 & & O & $\mathrm{O}$ & & $\mathrm{O}$ & & $\begin{array}{l}\begin{array}{l}\text { Holomediter- } \\
\text { rán }\end{array} \\
\end{array}$ & Sztyepp faj \\
\hline Rusina ferruginea & 0 & $\mathrm{O}$ & 0 & & $\mathrm{O}$ & $\mathrm{O}$ & & $\mathrm{O}$ & & Euroszibériai & Silvicol \\
\hline Athetis gluteosa & & & & & & & & $\mathrm{O}$ & & Szibériai & Lápréti faj \\
\hline Athetis lepigone & 0 & & & & & & & & $\mathrm{O}$ & Szibériai & Lápréti faj \\
\hline $\begin{array}{l}\text { Dypterygia scabri- } \\
\text { uscula }\end{array}$ & & & 0 & & & & $\mathrm{O}$ & & & Euroszibériai & Silvicol \\
\hline Trachea atriplicis & 0 & $\mathrm{O}$ & & & & $\mathrm{O}$ & & & & Euroszibériai & Silvicol \\
\hline $\begin{array}{l}\text { Polyphaenis } \\
\text { sericata }\end{array}$ & & O & 0 & & $\mathrm{O}$ & $\mathrm{O}$ & & $\mathrm{O}$ & & $\begin{array}{l}\begin{array}{l}\text { Holomediter- } \\
\text { rán }\end{array} \\
\end{array}$ & Quercetális \\
\hline $\begin{array}{l}\text { Thalpophila } \\
\text { matura }\end{array}$ & & & 0 & & & & & & $\mathrm{O}$ & Euroszibériai & Silvicol \\
\hline Actinotia polyodon & & & 0 & & & & & & & Szibériai & Láperdő faj \\
\hline Euplexia lucipara & & & 0 & & $\mathrm{O}$ & $\mathrm{O}$ & 0 & $\mathrm{O}$ & $\mathrm{O}$ & Euroszibériai & Láperdő faj \\
\hline $\begin{array}{l}\text { Phlogophora } \\
\text { meticulosa }\end{array}$ & & & 0 & & & $\mathrm{O}$ & & & & Euroszibériai & Silvicol \\
\hline $\begin{array}{l}\text { Helotropha leu- } \\
\text { costigma }\end{array}$ & 0 & & & & & & & & 0 & Szibériai & $\begin{array}{l}\text { Láprét-láper- } \\
\text { dei faj }\end{array}$ \\
\hline Gortyna flavago & 0 & & & & & & & & $\mathrm{O}$ & Szibériai & Arundifil \\
\hline $\begin{array}{l}\text { Hydraecia mica- } \\
\text { cea }\end{array}$ & 0 & & & & & & & & & Szibériai & $\begin{array}{l}\text { Láprét-láper- } \\
\text { dei faj }\end{array}$ \\
\hline Rhizedra lutosa & & & & & & & & & $\mathrm{O}$ & Szibériai & Arundifil \\
\hline Nonagria typhae & & & & & & & & & $\mathrm{O}$ & Szibériai & Arundifil \\
\hline $\begin{array}{l}\text { Lenisa gemini- } \\
\text { pucta }\end{array}$ & & & & & & & & $\mathrm{O}$ & & Szibériai & Arundifil \\
\hline $\begin{array}{l}\text { Archanara dis- } \\
\text { soluta }\end{array}$ & & & & & & & & & 0 & Szibériai & Arundifil \\
\hline Archanara neurica & 0 & & & & & & & & & Szibériai & Arundifil \\
\hline Globia sparganii & & & & & & & & & $\mathrm{O}$ & Euroszibériai & Arundifil \\
\hline $\begin{array}{l}\text { Apamea mono- } \\
\text { glypha }\end{array}$ & & & & & & $\mathrm{O}$ & & & & Szibériai & $\begin{array}{l}\text { Altoherbosa } \\
\text { faj }\end{array}$ \\
\hline $\begin{array}{l}\text { Mesapamea } \\
\text { secalis/secalella }\end{array}$ & & 0 & 0 & & $\mathrm{O}$ & & & $\mathrm{O}$ & 0 & Szibériai & Silvicol \\
\hline Oligia latruncula & & & 0 & & $\mathrm{O}$ & & & & & Euroszibériai & Euryök \\
\hline Oligia strigilis & & & 0 & & & & & & & Euroszibériai & Euryök \\
\hline Oligia versicolor & & & & & & & & & 0 & Szibériai & $\begin{array}{l}\text { Altoherbosa } \\
\text { faj }\end{array}$ \\
\hline Ipimorpha retusa & 0 & & & & $\mathrm{O}$ & & & & $\mathrm{O}$ & Szibériai & Láperdő faj \\
\hline
\end{tabular}




\begin{tabular}{|c|c|c|c|c|c|c|c|c|c|c|c|}
\hline Faj \ Lelőhely & $\begin{array}{c}1 \\
\text { MVB }\end{array}$ & $\begin{array}{l}2 \\
\text { MGT }\end{array}$ & $\begin{array}{c}3 \\
\text { MG }\end{array}$ & $\begin{array}{c}4 \\
\mathrm{AM}\end{array}$ & $\begin{array}{c}5 \\
S D\end{array}$ & $\begin{array}{c}6 \\
\text { SH }\end{array}$ & $\begin{array}{c}7 \\
\text { KSZ }\end{array}$ & $\begin{array}{c}8 \\
K K\end{array}$ & $\begin{array}{c}9 \\
\text { TD }\end{array}$ & $\begin{array}{c}\text { Állatföld- } \\
\text { rajzi } \\
\text { beosztás }\end{array}$ & $\begin{array}{l}\text { Ökológiai } \\
\text { beosztás }\end{array}$ \\
\hline Cosmia pyralina & & & & & $\mathrm{O}$ & & & & & Euroszibériai & Láperdő faj \\
\hline Cosmia trapezina & $\mathrm{O}$ & 0 & $\mathrm{O}$ & & 0 & 0 & & 0 & $\mathrm{O}$ & Euroszibériai & Silvicol \\
\hline Atethmia centrago & & 0 & & & & & & & & \begin{tabular}{|l|}
$\begin{array}{l}\text { Holomediter- } \\
\text { rán }\end{array}$ \\
\end{tabular} & Quercetális \\
\hline $\begin{array}{l}\text { Tiliacea sulphura- } \\
\text { go }\end{array}$ & & & & & & $\mathrm{O}$ & & & & $\begin{array}{l}\text { Holomediter- } \\
\text { rán }\end{array}$ & Quercetális \\
\hline Tiliacea citrago & & & 0 & & & & & & & $\begin{array}{l}\text { Holomediter- } \\
\text { rán }\end{array}$ & Quercetális \\
\hline Tiliacea aurago & & & & & $\mathrm{O}$ & $\mathrm{O}$ & & & & $\begin{array}{l}\text { Holomediter- } \\
\text { rán }\end{array}$ & Quercetális \\
\hline $\begin{array}{l}\text { Eupsilia trans- } \\
\text { versa }\end{array}$ & $\mathrm{O}$ & & $\mathrm{O}$ & & & $\mathrm{O}$ & & & & Euroszibériai & Silvicol \\
\hline $\begin{array}{l}\text { Lithophane orni- } \\
\text { thopus }\end{array}$ & & $\mathrm{O}$ & O & & $\mathrm{O}$ & $\mathrm{O}$ & & & & Euroszibériai & \begin{tabular}{|l} 
Altoherbosa- \\
nemorális faj
\end{tabular} \\
\hline $\begin{array}{l}\text { Aporophyla lutu- } \\
\text { lenta }\end{array}$ & & & & & & & & & $\mathrm{O}$ & Ponto-Kaszpi & $\begin{array}{l}\text { Pusztagyepi } \\
\text { faj }\end{array}$ \\
\hline Griposia aprilina & & & $\mathrm{O}$ & & $\mathrm{O}$ & $\mathrm{O}$ & & & & \begin{tabular}{|l|}
$\begin{array}{l}\text { Holomediter- } \\
\text { rán }\end{array}$ \\
\end{tabular} & Quercetális \\
\hline $\begin{array}{l}\text { Conistra erythro- } \\
\text { cephala }\end{array}$ & & & 0 & & 0 & $\mathrm{O}$ & & $\mathrm{O}$ & & Euroszibériai & Silvicol \\
\hline Conistra vaccinii & & $\mathrm{O}$ & $\mathrm{O}$ & & $\mathrm{O}$ & $\mathrm{O}$ & & & & Euroszibériai & Silvicol \\
\hline $\begin{array}{l}\text { Conistra rubigi- } \\
\text { nosa }\end{array}$ & & & $\mathrm{O}$ & & 0 & 0 & & & & Euroszibériai & Silvicol \\
\hline Conistra rubiginea & & & $\mathrm{O}$ & & $\mathrm{O}$ & & & & & Euroszibériai & Silvicol \\
\hline Agrochola nitida & & 0 & & & & & & $\mathrm{O}$ & & \begin{tabular}{|l|} 
Pontomedi- \\
terrán
\end{tabular} & Quercetális \\
\hline Agrochola humilis & & & & & 0 & & & & & \begin{tabular}{|l|}
$\begin{array}{l}\text { Holomediter- } \\
\text { rán-iráni }\end{array}$ \\
\end{tabular} & Quercetális \\
\hline $\begin{array}{l}\text { Agrochola circel- } \\
\text { laris }\end{array}$ & & $\mathrm{O}$ & & & 0 & 0 & & 0 & 0 & Euroszibériai & Silvicol \\
\hline Agrocola litura & & & & & $\mathrm{O}$ & $\mathrm{O}$ & & & & $\begin{array}{l}\text { Holomediter- } \\
\text { rán }\end{array}$ & Quercetális \\
\hline Agrochola helvola & & & & & & $\mathrm{O}$ & & & & \begin{tabular}{|l|} 
Euroszibériai \\
\end{tabular} & Silvicol \\
\hline Xanthia ocellaris & & & & & & 0 & & & & Szibériai & Nyár-füz faj \\
\hline Xanthia icteritia & $\mathrm{O}$ & & & & & & & & & Szibériai & Nyár-füz faj \\
\hline $\begin{array}{l}\text { Parastichtis sus- } \\
\text { pecta }\end{array}$ & & & 0 & & & & & & $\mathrm{O}$ & Euroszibériai & Nyár-füz faj \\
\hline $\begin{array}{l}\text { Apterogenum } \\
\text { ypsillon }\end{array}$ & 0 & & & & & & & & & Szibériai & Láperdő faj \\
\hline Blepharita satura & & & 0 & & 0 & 0 & & 0 & & $\begin{array}{l}\text { Holomediter- } \\
\text { rán }\end{array}$ & Quercetális \\
\hline Mythimna turca & & & $\mathrm{O}$ & $\mathrm{O}$ & $\mathrm{O}$ & & $\mathrm{O}$ & & $\mathrm{O}$ & Szibériai & Mezofil \\
\hline Mythimna ferrago & & & 0 & & $\mathrm{O}$ & $\mathrm{O}$ & & $\mathrm{O}$ & $\mathrm{O}$ & Euroszibériai & Lápréti faj \\
\hline Mythimna vitellina & & & & & $\mathrm{O}$ & & & & $\mathrm{O}$ & $\begin{array}{l}\text { Holomediter- } \\
\text { rán }\end{array}$ & Sztyepp faj \\
\hline Mythimna impura & $\mathrm{O}$ & & & & & & & & & Szibériai & Lápréti faj \\
\hline $\begin{array}{l}\text { Mythimna pu- } \\
\text { dorina }\end{array}$ & & & & & & & $\mathrm{O}$ & & $\mathrm{O}$ & Szibériai & Lápréti faj \\
\hline Mythimna pallens & $\mathrm{O}$ & & & & & & & & $\mathrm{O}$ & Euroszibériai & Euryök \\
\hline $\begin{array}{l}\text { Mythimna } \\
\text { straminea }\end{array}$ & & & & & & & & $\mathrm{O}$ & & Szibériai & Lápréti faj \\
\hline Mythimna I-album & & $\mathrm{O}$ & & & $\mathrm{O}$ & & & $\mathrm{O}$ & $\mathrm{O}$ & \begin{tabular}{|l|} 
Euroszibériai \\
\end{tabular} & Euryök \\
\hline Leucania obsoleta & & & & $\mathrm{O}$ & & & & & & Euroszibériai & Arundifil \\
\hline Senta flammea & $\mathrm{O}$ & & & & & & & & $\mathrm{O}$ & Szibériai & Arundifil \\
\hline
\end{tabular}




\begin{tabular}{|c|c|c|c|c|c|c|c|c|c|c|c|}
\hline Faj \ Lelőhely & $\begin{array}{c}1 \\
\text { MVB }\end{array}$ & $\stackrel{2}{2}$ & $\begin{array}{c}3 \\
\text { MG }\end{array}$ & $\begin{array}{c}4 \\
\text { AM }\end{array}$ & $\begin{array}{c}5 \\
\text { SD }\end{array}$ & $\begin{array}{c}6 \\
\text { SH }\end{array}$ & $\begin{array}{l}7 \\
\text { KSZ }\end{array}$ & $\begin{array}{c}8 \\
K K\end{array}$ & $\begin{array}{c}9 \\
\text { TD }\end{array}$ & $\begin{array}{c}\text { Állatföld- } \\
\text { rajzi } \\
\text { beosztás }\end{array}$ & $\begin{array}{l}\text { Ökológiai } \\
\text { beosztás }\end{array}$ \\
\hline Hadula trifolii & & & & & & $\mathrm{O}$ & & & 0 & Euroszibériai & Euryök \\
\hline Conisania luteago & & & & & & & $\mathrm{O}$ & $\mathrm{O}$ & $\mathrm{O}$ & $\begin{array}{l}\text { Holomediter- } \\
\text { rán-iráni }\end{array}$ & Sztyepp faj \\
\hline Sideridis rivularis & & & 0 & & & & & & $\mathrm{O}$ & Euroszibériai & Silvicol \\
\hline $\begin{array}{l}\text { Mamestra bras- } \\
\text { sicae }\end{array}$ & & & & & $\mathrm{O}$ & $\mathrm{O}$ & $\mathrm{O}$ & & & Euroszibériai & Euryök \\
\hline $\begin{array}{l}\text { Melanchra persi- } \\
\text { cariae }\end{array}$ & & & & & & & O & & $\mathrm{O}$ & Szibériai & Mezofil \\
\hline $\begin{array}{l}\text { Lacanobia olera- } \\
\text { cea }\end{array}$ & & & 0 & & $\mathrm{O}$ & $\mathrm{O}$ & 0 & $\mathrm{O}$ & & Euroszibériai & Euryök \\
\hline $\begin{array}{l}\text { Lacanobia w- } \\
\text { latinum }\end{array}$ & & $\mathrm{O}$ & & & & & & & & $\begin{array}{l}\text { Holomediter- } \\
\text { rán }\end{array}$ & Sztyepp faj \\
\hline $\begin{array}{l}\text { Lacanobia thalas- } \\
\text { sina }\end{array}$ & & & & 0 & & & & & & Szibériai & Silvicol \\
\hline $\begin{array}{l}\text { Hadena capsin- } \\
\text { cola }\end{array}$ & & & & & & & & & $\mathrm{O}$ & Euroszibériai & Silvicol \\
\hline Panolis flammea & & & & & & & & $\mathrm{O}$ & & Szibériai & Pinetális \\
\hline Orthosia cerasi & & $\mathrm{O}$ & $\mathrm{O}$ & & $\mathrm{O}$ & $\mathrm{O}$ & & $\mathrm{O}$ & & $\begin{array}{l}\text { Holomediter- } \\
\text { rán }\end{array}$ & Quercetális \\
\hline Orthosia incerta & & $\mathrm{O}$ & 0 & & & $\mathrm{O}$ & & & & Euroszibériai & Silvicol \\
\hline Orthosia miniosa & & & & & & $\mathrm{O}$ & & & & Euroszibériai & Silvicol \\
\hline Orthosia cruda & & & $\mathrm{O}$ & & $\mathrm{O}$ & $\mathrm{O}$ & & & & $\begin{array}{l}\text { Holomediter- } \\
\text { rán }\end{array}$ & Quercetális \\
\hline $\begin{array}{l}\text { Dioszeghyana } \\
\text { schmidtii }\end{array}$ & & $\mathrm{O}$ & & & $\mathrm{O}$ & $\mathrm{O}$ & & & & \begin{tabular}{|l} 
Pontomedi- \\
terrán
\end{tabular} & Quercetális \\
\hline Orthosia gothica & & $\mathrm{O}$ & $\mathrm{O}$ & & $\mathrm{O}$ & $\mathrm{O}$ & & $\mathrm{O}$ & & Euroszibériai & Silvicol \\
\hline Anorthoa munda & & & $\mathrm{O}$ & & & $\mathrm{O}$ & & & & Euroszibériai & Silvicol \\
\hline $\begin{array}{l}\text { Egira conspicil- } \\
\text { laris }\end{array}$ & & & & & & $\mathrm{O}$ & & $\mathrm{O}$ & & $\begin{array}{l}\text { Holomediter- } \\
\text { rán }\end{array}$ & Quercetális \\
\hline Agrotis segetum & & $\mathrm{O}$ & $\mathrm{O}$ & $\mathrm{O}$ & $\mathrm{O}$ & $\mathrm{O}$ & & & $\mathrm{O}$ & Euroszibériai & Euryök \\
\hline Agrotis ipsilon & & & 0 & $\mathrm{O}$ & & $\mathrm{O}$ & & & & Vándor & Euryök \\
\hline $\begin{array}{l}\text { Agrotis exclama- } \\
\text { tionis }\end{array}$ & $\mathrm{O}$ & & $\mathrm{O}$ & 0 & $\mathrm{O}$ & $\mathrm{O}$ & $\mathrm{O}$ & $\mathrm{O}$ & $\mathrm{O}$ & Euroszibériai & Euryök \\
\hline Axylia putris & $\mathrm{O}$ & 0 & $\mathrm{O}$ & 0 & & $\mathrm{O}$ & $\mathrm{O}$ & $\mathrm{O}$ & $\mathrm{O}$ & $\begin{array}{l}\text { Holomediter- } \\
\text { rán }\end{array}$ & Vándor \\
\hline $\begin{array}{l}\text { Ochropleura } \\
\text { plecta }\end{array}$ & & & $\mathrm{O}$ & $\mathrm{O}$ & & $\mathrm{O}$ & $\mathrm{O}$ & & $\mathrm{O}$ & Euroszibériai & Euryök \\
\hline Opigena polygona & & & & & & & & & $\mathrm{O}$ & \begin{tabular}{|l|} 
Holomediter- \\
rán-turkesz- \\
táni
\end{tabular} & Sztyepp faj \\
\hline $\begin{array}{l}\text { Metagnorisma } \\
\text { depuncta }\end{array}$ & & & 0 & & $\mathrm{O}$ & $\mathrm{O}$ & & & $\mathrm{O}$ & \begin{tabular}{|l|} 
Pontomedi- \\
terrán-kasz- \\
pi-turkesztáni
\end{tabular} & Quercetális \\
\hline Noctua pronuba & & 0 & 0 & & $\mathrm{O}$ & $\mathrm{O}$ & & $\mathrm{O}$ & $\mathrm{O}$ & $\begin{array}{l}\text { Holomediter- } \\
\text { rán }\end{array}$ & Sztyepp faj \\
\hline Noctua fimbriata & $\mathrm{O}$ & $\mathrm{O}$ & & & $\mathrm{O}$ & $\mathrm{O}$ & & $\mathrm{O}$ & $\mathrm{O}$ & $\begin{array}{l}\text { Holomediter- } \\
\text { rán }\end{array}$ & Sztyepp faj \\
\hline Noctua comes & & & & & O & $\mathrm{O}$ & & O & O & $\begin{array}{l}\text { Holomediter- } \\
\text { rán }\end{array}$ & Sztyepp faj \\
\hline Noctua interposita & $\mathrm{O}$ & 0 & & & & & & & $\mathrm{O}$ & $\begin{array}{l}\text { Holomediter- } \\
\text { rán }\end{array}$ & Sztyepp faj \\
\hline Noctua janthe & & & $\mathrm{O}$ & & $\mathrm{O}$ & 0 & & & O & $\begin{array}{l}\text { Holomediter- } \\
\text { rán }\end{array}$ & Silvicol \\
\hline Noctua janthina & & & & & $\mathrm{O}$ & & & & & $\begin{array}{l}\text { Holomediter- } \\
\text { rán }\end{array}$ & Silvicol \\
\hline
\end{tabular}




\begin{tabular}{|c|c|c|c|c|c|c|c|c|c|c|c|}
\hline Faj \ Lelőhely & $\begin{array}{c}1 \\
\text { MVB }\end{array}$ & $\stackrel{2}{\text { MGT }}$ & $\begin{array}{c}3 \\
\text { MG }\end{array}$ & $\begin{array}{c}4 \\
\text { AM }\end{array}$ & $\begin{array}{c}5 \\
\text { SD }\end{array}$ & $\begin{array}{c}6 \\
\text { SH }\end{array}$ & $\begin{array}{c}7 \\
\text { KSZ }\end{array}$ & $\begin{array}{c}8 \\
K K\end{array}$ & $\begin{array}{c}9 \\
\text { TD }\end{array}$ & $\begin{array}{c}\text { Állatföld- } \\
\text { rajzi } \\
\text { beosztás }\end{array}$ & $\begin{array}{l}\text { Ökológiai } \\
\text { beosztás }\end{array}$ \\
\hline Noctua interjecta & & $\mathrm{O}$ & & & & & & & & $\begin{array}{l}\text { Atlanto-medi- } \\
\text { terrán }\end{array}$ & Quercetális \\
\hline Xestia c-nigrum & $\mathrm{O}$ & & $\mathrm{O}$ & & $\mathrm{O}$ & $\mathrm{O}$ & & $\mathrm{O}$ & $\mathrm{O}$ & Euroszibériai & Euryök \\
\hline $\begin{array}{l}\text { Xestia xan- } \\
\text { thographa }\end{array}$ & & $\mathrm{O}$ & & & $\mathrm{O}$ & $\mathrm{O}$ & & & $\mathrm{O}$ & $\begin{array}{l}\text { Atlanto-medi- } \\
\text { terrán }\end{array}$ & Silvicol \\
\hline Xestia triangulum & $\mathrm{O}$ & $\mathrm{O}$ & $\mathrm{O}$ & & $\mathrm{O}$ & $\mathrm{O}$ & & $\mathrm{O}$ & & Szibériai & $\begin{array}{l}\text { Altoherbosa } \\
\text { faj }\end{array}$ \\
\hline Xestia stigmatica & & & $\mathrm{O}$ & & $\mathrm{O}$ & & & & & Szibériai & Silvicol \\
\hline Naenia typica & & $\mathrm{O}$ & & & & & & & & Szibériai & Láperdő faj \\
\hline $\begin{array}{l}\text { Cerastis } \\
\text { leucographa }\end{array}$ & & & $\mathrm{O}$ & & & $\mathrm{O}$ & & & & Szibériai & Nemorális \\
\hline
\end{tabular}

\section{Irodalom}

ÁBRAHÁm L. 1992a: Boronka-melléki Tájvédelmi Körzet nagylepke faunájának természetvédelmi feltárása I. (Lepidoptera). Dunántúli Dolgozatok Természettudományi Sorozat 7: pp. 241-271.

ÁBRAHÁM L 1992b: A Zselici Tájvédelmi Körzet Macrolepidotrea faunájának ismeretéhez (Lepidoptera). Somogyi Múzeumok Közleményei 9: pp. 293-306.

ÁBRAHÁM L. 2003: A Látrányi Puszta Természetvédelmi Terület nagylepke (Lepidoptera) faunájának vizsgálata. Natura Somogyiensis 5: pp. 241-254.

ÁbrahÁm L. és UherkoVich Á. 2001: Somogy nagylepke faunájának katalógusa (Lepidoptera: Macrolepidoptera). Natura Somogyiensis 1: pp. 329-374.

DöVÉNYI Z. 2010: Magyarország kistájainak katasztere. MTA Földrajztudományi Kutatóintézet, Budapest.

KovÁcs L. 1953: A magyarországi nagylepkék és elterjedésük, Folia Entomologica Hungarica 6 (1): pp. 77-184.

KovÁcs L. 1956: A magyarországi nagylepkék és elterjedésük II. Folia Entomologica Hungarica 9 (1): pp. 89-140.

MAGYAR KÖZLÖNY, 158. szám, 66/2015 (X. 26) FM rendelet

RÉZBÁNYAI L. 1972: Vizsgálatok a Balaton délkeleti (BalatonszabadiZamárdi) partvidékének nagylepke-faunáján (Lepidoptera) Folia Entomologica 25(2): pp. 229-252.

SCHMIDT P. 2019: A cserszömörcebagoly (Eutelia adulatrix) újabb So- mogy megyei elöfordulása (Lepidoptera). Natura Somogyiensis 33: pp 11-12.

SzABó G. 2007: Adatok a Dunántúli-dombság nagylepke faunájához (Lepidoptera: Macrolepidoptera). Natura Somogyiensis 10: pp. 331-339.

UHERKoVICH Á. 1975: Adatok Baranya nagylepkefaunájának ismeretéhez IV. A Villányi-hegység nappali lepkéi, A Janus Pannonius Múzeum Évkönyve 17-18. pp. 33-43.

UHERKOVICH Á. 1978a: Belső-Somogy és a Zselic határvidékének lepidopterológiai viszonyai (Lepidoptera). Somogyi Múzeumok Közleményei 3: pp. 503-518.

UHERKOVICH Á. 1978b: A Barcsi Ösborókás nagylepkefaunája (Lepidop-tera). Dunántúli Dolgozatok Természettudományi Sorozat 1: pp. 93-125.

UHERKovich Á. 1981a: A Zselici Tájvédelmi Körzet nagylepkefaunája. Somogyi Múzeumok Közleményei IV./1. különlenyomat. p. 9.

VARGA Z. 1964: Magyarország állatföldrajzi beosztása a nagylepke-fauna komponensei alapján. Rovartani Közlemények. TOM. XVII.: pp. 119-167.

VARGA Z. 2003: Magyar tudománytár 3 Növény, állat, élöhely, MTA Társadalomkutató Központ, Kossuth Kiadó, Budapest

VARGA Z. SZERK. 2010: Magyarország nagylepkéi. Heterocera Press, Budapest. 